\title{
Facies, palynostratigraphy and sequence stratigraphy of the Wilhelmøya Subgroup (Upper Triassic-Middle Jurassic) in western central Spitsbergen, Svalbard
}

\author{
Bjarte Rismyhr 1,2, Tor Biærke ${ }^{3}$, Snorre Olaussen², Mark Joseph Mulrooney ${ }^{2,4}$ \\ \& Kim Senger ${ }^{2}$ \\ ${ }^{1}$ Department of Earth Science, University of Bergen, P.O. Box 7803, N-5020 Bergen, Norway. \\ ${ }^{2}$ Department of Arctic Geology, University Centre in Svalbard, P.O. Box 156, 9171 Longyearbyen, Norway. \\ ${ }^{3}$ Applied Petroleum Technology AS, P.O. Box 173, Kalbakken, 0903 Oslo. \\ ${ }^{4}$ Department of Geoscience, University of Oslo, P.O. Box 1047 Blindern, 0316 Oslo, Norway. \\ E-mail corresponding author (Bjarte Rismyhr):bjarte.rismyhr@gmail.com
}

\begin{abstract}
The Wilhelmøya Subgroup (Norian-Bathonian) is considered as the prime storage unit for locally produced $\mathrm{CO}_{2}$ in Longyearbyen on the Arctic archipelago of Svalbard. We here present new drillcore and outcrop data and refined sedimentological and sequence-stratigraphic interpretations from western central Spitsbergen in and around the main potential $\mathrm{CO}_{2}$-storage area. The Wilhelmøya Subgroup encompasses a relatively thin $(15-24 \mathrm{~m})$ siliciclastic succession of mudstones, sandstones and conglomerates and represents an unconventional potential reservoir unit due to its relatively poor reservoir properties, i.e., low-moderate porosity and low permeability. Thirteen sedimentary facies were identified in the succession and subsequently grouped into five facies associations, reflecting deposition in various marginal marine to partly sediment-starved, shallow shelf environments. Palynological analysis was performed to determine the age and aid in the correlation between outcrop and subsurface sections. The palynological data allow identification of three unconformity-bounded sequences (sequence 1-3). These sequences record intermittent deposition in the Early Norian, Early-Middle Toarcian, and Late Toarcian-Aalenian, interrupted by extended periods of erosion, bypass and/or non-deposition. The stratigraphically condensed development of the Wilhelmøya Subgroup in western central Spitsbergen is interpreted to be the result of very low subsidence rates coupled with a physiographic setting characterised by a very gentle depositional gradient. This facilitated rapid shoreline shifts in response to even relatively modest variations in relative sea level with considerable influence on the resulting depositional patterns. We present a revised depositional model for the regionally distinct Brentskardhaugen Bed at the top of the Wilhelmøya Subgroup involving condensation and partial reworking of a series of Upper Toarcian-Aalenian, high-frequency sequences. Coarse-grained extraformational fractions observed within conglomerates of the Wilhelmøya Subgroup are suggested to have been supplied from uplifted and exposed margins to the west (northern Greenland) and north (northern Svalbard).
\end{abstract}

Keywords: Wilhelmøya Subgroup, Brentskardhaugen Bed, sequence stratigraphy, facies analysis, palynology, condensed unit

Received 1. November 2017 / Accepted 15. April 2018 / Published online 19. October 2018

\section{Introduction}

The Longyearbyen $\mathrm{CO}_{2} \mathrm{Lab}\left(\mathrm{LYB} \mathrm{CO}_{2}\right.$ ) project is a joint ongoing effort by academic and industry partners to establish a test facility for the underground storage of $\mathrm{CO}_{2}$ in the vicinity of Longyearbyen on the Norwegian Arctic archipelago of Svalbard (e.g., Braathen et al., 2012;
Senger et al., 2015). The prime source for the $\mathrm{CO}_{2}$ is the coal-fuelled power plant in Longyearbyen, emitting c. 70,000 tons of $\mathrm{CO}_{2}$ annually, and a suitable target formation has been identified in the siliciclastic Kapp Toscana Group at c. 670-970 m depth. To date, a diverse collection of subsurface and field data have been acquired and analysed as part of the project, including more than

Rismyhr, B., Bjærke, T., Olaussen, S., Mulrooney, M.J. \& Senger, K. 2019: Facies, palynostratigraphy and sequence stratigraphy of the Wilhelmøya Subgroup (Upper Triassic-Middle Jurassic) in western central Spitsbergen, Svalbard. Norwegian Journal of Geology 99, 183-212.

https://dx.doi.org/10.17850/njg001. 

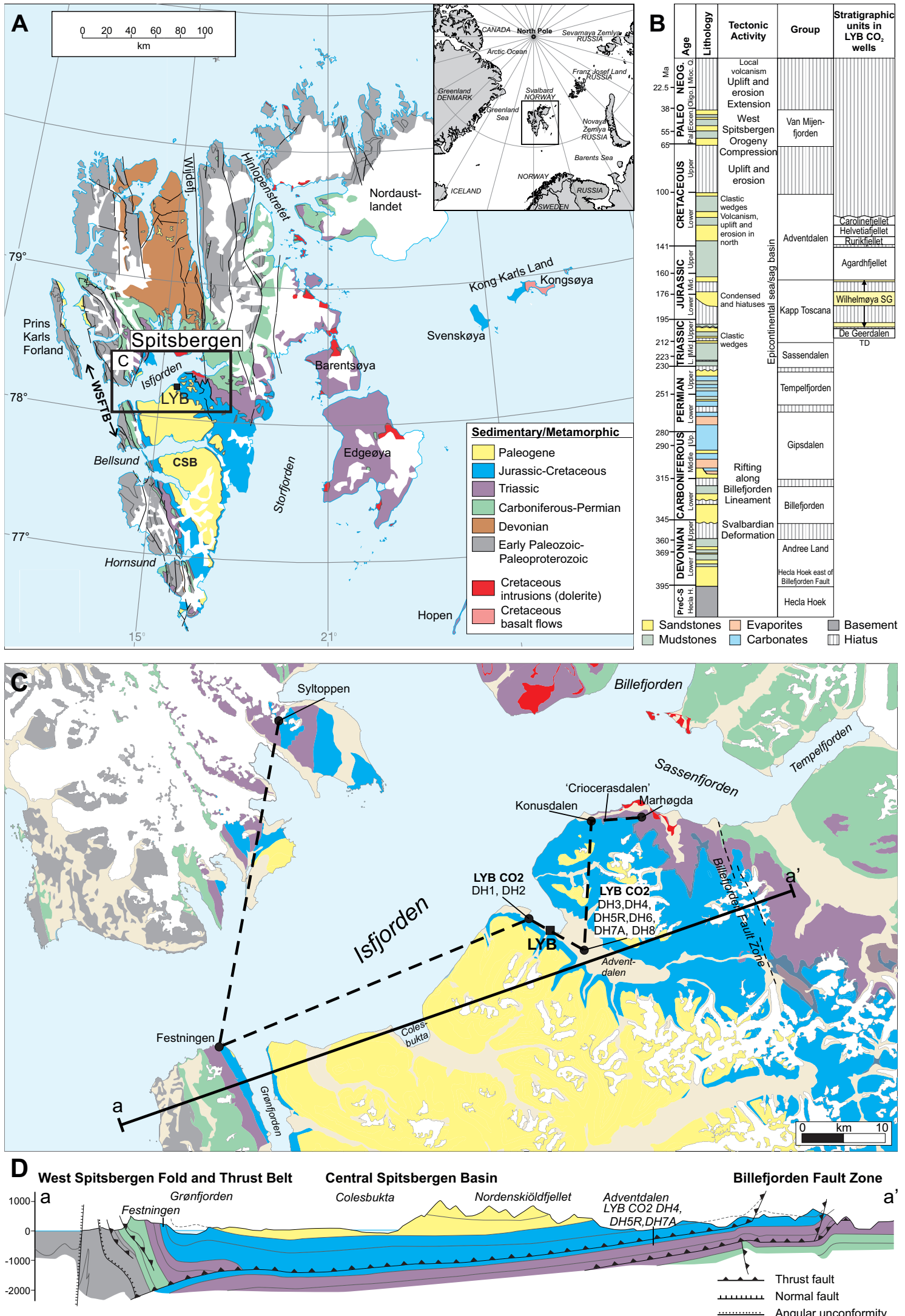

Figure 1. Regional, geological and stratigraphic setting of Svalbard. (A) Simplified geological map of the Svalbard archipelago with the study area marked by a rectangle. Inset map shows the geographic location of Svalbard. Geological map modified from @Norwegian Polar Institute, npolar.no. (B) Simplified stratigraphic column of Svalbard, drilled formations in the $\mathrm{CO}_{2}$ wells and overview of main tectonic phases since the Precambrian. Adapted from Nøttvedt et al. (1993b). (C) Close-up of study area with location of drill sites and investigated outcrop sections. Dashed line shows correlation line used in Fig. 11. Map modified from @Norwegian Polar Institute, npolar.no. (D) Geological crosssection of the study area with projected position of wells and the Festningen outcrop section. Redrawn and modified from Dallmann (2015). Abbreviations: WSFTB - West Spitsbergen Fold and Thrust Belt, CSB - Central Spitsbergen Basin, LYB - Longyearbyen, TD - total depth. 
$4 \mathrm{~km}$ of drillcore from 8 onshore slimhole wells drilled near Longyearbyen (Fig. 1). Previous studies have shown that the targeted storage unit is underpressured and compartmentalised (Braathen et al., 2012; Senger et al., 2015; Mulrooney et al., 2019), and characterised by moderate porosities and low matrix permeabilities (i.e., unconventional reservoir) due to extensive mechanical and chemical compaction (Farokhpoor et al., 2010; Mørk, 2013). Water injection tests and numerical simulations, however, indicate relatively good lateral fluid flow facilitated by an extensive network of natural fractures (Braathen et al., 2012; Ogata et al., 2012, 2014; Van Stappen et al., 2014; Mulrooney et al., 2019) which also contribute to the overall storage capacity (Senger et al., 2015).

The upper part of the Kapp Toscana Group, comprising conglomerates, sandstones and mudstones of the stratigraphically condensed, Early Norian-Bathonian, Wilhelmøya Subgroup (Figs. 1B \& 2; Mørk et al., 1999), offers the best reservoir properties and is considered the most promising reservoir interval (Braathen et al., 2012). Since both diagenetic effects and the intensity, distribution and orientation of natural fractures have been shown to vary considerably with lithology and sedimentary facies (Ogata et al., 2012, 2014; Mørk, 2013), determination of the internal facies distribution within the Wilhelmøya Subgroup is therefore of significant importance. This can subsequently be used as input into increasingly more detailed reservoir models (Mulrooney et al., 2019), volumetric calculations and storage resource estimates (Senger et al., 2015), and contribute to improved predictions of $\mathrm{CO}_{2}$ injection behaviour and subsequent migration trends.

In this contribution, we refine the facies and sequencestratigraphic interpretations of the Wilhelmøya Subgroup in and around the $\mathrm{CO}_{2}$ storage area based on extensive new field and drillcore data. This was accomplished through detailed facies analysis of drillcores and outcrop material, with new palynological data from core samples providing a framework for sequence delineation and

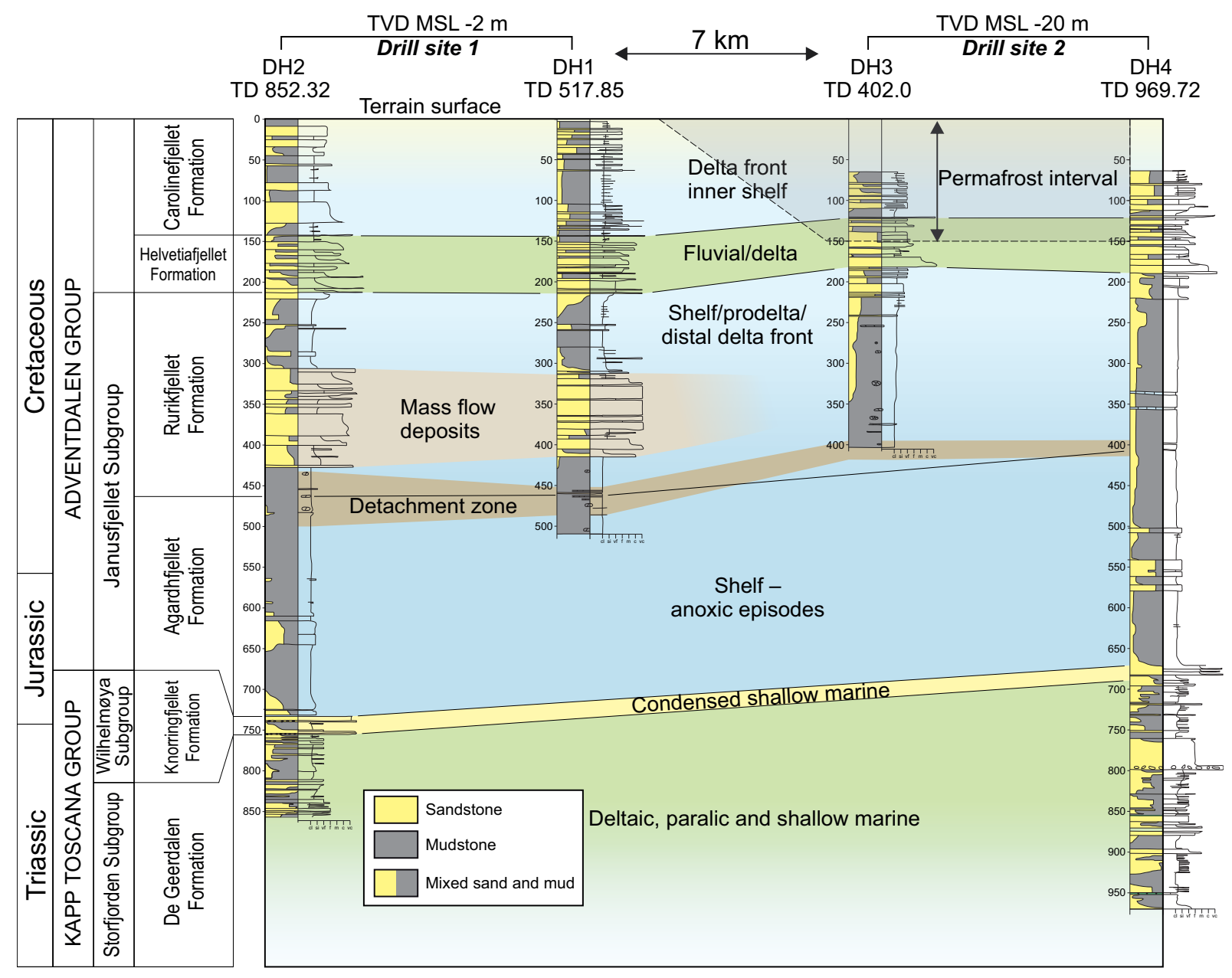

Figure 2. Overview of the stratigraphy penetrated by the initial four wells drilled as part of the Longyearbyen $\mathrm{CO}_{2}$ Lab project drilling campaign. The reservoir interval is formed by the Kapp Toscana Group, which includes deltaic, paralic and shallow-marine deposits of the De Geerdalen Formation, and condensed shallow-marine deposits of the Wilhelmøya Subgroup. A thick caprock succession, consisting of shelf, prodelta and distal delta-front deposits of the Agardhfjellet and Rurikfjellet formations, overlies the reservoir interval. The location of wells and drillsites is shown in Fig. 1. Redrawn and modified from Ogata et al. (2012). 
correlation between subsurface and nearby outcrop sections. The unique core material also offers new data points and further insight into the regional development of the Wilhelmøya Subgroup, which may ultimately also be relevant for hydrocarbon-bearing deposits of the time-equivalent Realgrunnen Subgroup in the southwestern Barents Sea (e.g., Henriksen et al., 2011b).

\section{Geological setting}

The Svalbard archipelago, with Spitsbergen as its largest island, is part of the Eurasian continental plate and is located on the uplifted and exhumed northwestern corner of the present-day Barents shelf (Fig. 1; e.g., Nøttvedt et al., 1993b; Worsley, 2008). Geologically, the Barents shelf represents an intracratonic basin bounded by passive margins on its western and northern flanks that developed in response to the Cenozoic opening of the Norwegian-Greenland Sea and the Eurasia Basin, respectively (Faleide et al., 2015).

During the Mesozoic, the Barents shelf area was part of a large epicontinental sea surrounded by the Pangaea supercontinent to the west, south and east, and with an open connection towards the Boreal part of the Panthalassa Ocean towards the northwest (Riis et al., 2008). Sag basin subsidence characterised the region through most of the Triassic, and a thick siliciclastic succession was deposited recording delta progradation towards the north and northwest following influx of large volumes of sediments sourced from the Uralides to the southeast and east (Riis et al., 2008; Glørstad-Clark et al., 2010). In Svalbard, the Lower-Middle Triassic strata record intermittent sediment input from a westerly Laurentian (North Greenland) source (Steel \& Worsley, 1984; Bue \& Andresen, 2013), but a shift occurred in the Late Triassic as the Uralide-sourced systems eventually reached Svalbard. By the end of the Carnian an extensive low-gradient coastal/delta plain covered most of the Barents shelf (Riis et al., 2008; Høy \& Lundschien, 2011; Klausen et al., 2015).

Following a major flooding event in the Early Norian, open marine environments re-established throughout the region. The transgression was accompanied by a significant decrease in subsidence rates, changes in provenance areas and drainage patterns in the latest Triassic-Early Jurassic (Steel \& Worsley, 1984; Bergan \& Knarud, 1993; Henriksen et al., 2011b; Ryseth, 2014; Fleming et al., 2016). This was probably the result of subhorizontal compressional forces and forebulge development in the central Barents shelf area in response to the Novaya Zemlya protrusion of the Uralide-Taimyr fold-and-thrust belt in the Late Triassic-Early Jurassic (Buiter \& Torsvik, 2007; Petrov et al., 2008; Ritzmann \& Faleide, 2009; Klausen et al., 2017), as well as uplift and possible rejuvenation of more proximal areas and basin margins in the southwest (Hendriks \& Andriessen, 2002; Ryseth, 2014), northwest (Nøttvedt et al., 1993b; Grogan et al., 1999; Bue \& Andresen, 2013) and north-northeast (Buiter \& Torsvik, 2007; Dörr et al., 2012). The resulting Upper Triassic-Middle Jurassic succession records deposition of compositionally mature (Mørk et al., 1982; Bergan \& Knarud, 1993; Mørk, 1999) shallow-marine to coastal sediments within local basins (Olaussen et al., 1984; Gjelberg et al., 1987; Henriksen et al., 2011b) and becomes thinner, stratigraphically condensed and characterised by several internal disconformities towards the basin margins and over regional platforms and highs (Steel \& Worsley, 1984; Johannessen \& Embry, 1989; Nøttvedt et al., 1993a; Smelror et al., 2009; Henriksen et al., 2011b; Ryseth, 2014; Klausen et al., 2017, 2018), indicating important lateral variations in accommodation space.

A late Middle Jurassic unconformity and renewed regional transgression marks the onset of rifting in the western Barents shelf (Faleide et al., 2015). Previously exposed platforms and highs became submerged and restricted bottom circulation led to the accumulation of anoxic black shales in Svalbard and the southwestern Barents shelf in the Late Jurassic (e.g., Koevoets et al., 2019). The subsequent geological development of the region was characterised by several phases of uplift and erosion, as well as extensional and strike-slip movements along the western margin of the Barents shelf which culminated with the opening of the NorwegianGreenland Sea in the Cenozoic (Faleide et al., 1993). Circum-Arctic basaltic magmatic activity during the Early Cretaceous, i.e., the High Arctic Large Igneous Province (HALIP), resulted in the emplacement of numerous sills and dykes in the study area (e.g., Senger et al., 2014). The associated thermal uplift led to a major shift in depositional direction, with the Cretaceous units reflecting a northerly source area (e.g., Grundvåg et al., 2017). In Svalbard, the development of the West Spitsbergen Fold-and-Thrust Belt (WSFTB) and the associated Central Spitsbergen Basin (CSB) in the Palaeocene-Eocene (Steel et al., 1985; Bergh et al., 1997), as well as uplift and erosion during the latest PalaeogeneQuaternary (e.g., Dimakis et al., 1998; Henriksen et al., 2011a) all represent notable events which had a significant impact on the properties and orientation of Mesozoic strata within the study area.

\section{Stratigraphy of the study area}

The two Longyearbyen $\mathrm{CO}_{2}$ Lab well sites are situated on the eastern limb of the narrow, NNW-SSE-elongated Central Spitsbergen Basin (Fig. 1). The strata of the Kapp Toscana Group dip gently $\left(1-3^{\circ}\right)$ towards the southwest (Bælum et al., 2012) and are encountered at depths below 
c. $670 \mathrm{~m}$ at the proposed $\mathrm{CO}_{2}$ storage site in Adventdalen. Towards the northeast the upper part of the Kapp Toscana Group is exposed in a series of small valleys (e.g., Konusdalen and 'Criocerasdalen') and in mountainsides (e.g., Marhøgda) at the southern margin of Sassenfjorden (Fig. 1C). At Festningen, in the western part of Isfjorden (Fig. 1C, D), the succession is involved in the WSFTB and is exposed at sea level in strata dipping steeply eastwards.

The Kapp Toscana Group attains a total thickness of 300$350 \mathrm{~m}$ in western central Spitsbergen and encompasses the Tschermakfjellet Formation (early Carnian), the De Geerdalen Formation (Carnian-?earliest Norian) and the Wilhelmøya Subgroup (early Norian-Bathonian; Figs. 1 \& 2). The nearly 300 m-thick De Geerdalen Formation makes up the dominant part of the Kapp Toscana Group and comprises repeated upward-coarsening units from shales to sandstones (Mørk et al., 1999), reflecting delta progradation mainly from the southeast (Rød et al., 2014; Klausen et al., 2015; Lord et al., 2017). The uppermost 70 $\mathrm{m}$ of the De Geerdalen Formation comprise the Isfjorden Member (Mørk et al., 1999), which is characterised by red- and green-weathering mudstones alternating with thin siltstones, sandstones, and occasional bivalve coquinas and calcrete palaeosol horizons. The Isfjorden Member records deposition in shallow shelf, lagoonal and delta-plain environments (Rød et al., 2014; Haugen, 2016; Lord et al., 2017).

The Wilhelmøya Subgroup sits disconformably on the De Geerdalen Formation and is only 15-24 m thick within the study area, which is in sharp contrast to the considerably thicker development observed in eastern Svalbard and in the correlative Realgrunnen Subgroup in the southwestern Barents shelf (e.g., Johannesen \& Embry, 1989; Mørk et al., 1999; Henriksen et al., 2011b). It is bounded above and below by phosphorite conglomerates and calcareous sandstones of two regionally distinct marker beds, the Slottet Bed and the Brentskardhaugen Bed (Bäckström \& Nagy, 1985; Mørk et al., 1999), at the base and top of the succession, respectively. Internally, the Wilhelmøya Subgroup in western central Spitsbergen includes shallow-marine mudstones, siltstones and sandstones (e.g., Mørk et al., 1982; Nagy \& Berge, 2008) which are currently included in the Norian-Bathonian Knorringfjellet Formation (Mørk et al., 1999).

The caprock is formed by a $500 \mathrm{~m}$-thick succession of offshore mudstones (locally organic rich) and siltstones of the Agardhfjellet Formation (Late BathonianLate Ryazanian/Early Valanginian), and prodelta and shoreface/delta-front deposits of the Rurikfjellet Formation (Valanginian-Early Barremian; Dypvik et al., 1991; Koevoets et al., 2019). These are in turn overlain by fluvio-deltaic to paralic sediments of the Helvetiafjellet Formation (Barremian) and prodelta and distal marine deposits of the Aptian-Albian Carolinefjellet Formation (Grundvåg et al., 2017).

\section{Lithostratigraphic remarks}

According to the current lithostratigraphic scheme for the Mesozoic in Svalbard (Mørk et al., 1999), the Wilhelmøya Subgroup comprises the Knorringfjellet Formation and two informally named subunits, the Tverrbekken and Teistberget members, within the study area. Some inconsistencies with this subdivision have led us to use the superior term (i.e., Wilhelmøya Subgroup), and instead employ a provisional subdivision based on generic sequences (sequences 1-3) separated by lithologically and/or biostratigraphically well-defined disconformities. The inconsistencies in the prevailing scheme will not be addressed in excessive detail here, but the following two remarks are made: (1) Although showing a considerably thinner development, the Tverrbekken member consists of deposits of comparable facies and age as the Early Norian Flatsalen Formation in eastern Svalbard (Mørk et al., 1999; Lord et al., 2017), and the latter could therefore have priority; (2) The Teistberget member has its type section at Teistberget, eastern Spitsbergen, but the term has not traditionally been applied to deposits outside central and western Spitsbergen. Since the Flatsalen, Svenskøya (NorianToarcian) and Kongsøya formations (ToarcianBathonian) all appear to be recognisable throughout eastern Spitsbergen (e.g., Lord et al., 2017) based on their current lithostratigraphic definitions (Mørk et al., 1999), the Teistberget member may be superfluous as a separate unit within its own defined type area.

The stratigraphic affiliation of the Brentskardhaugen Bed has been disputed (see Mørk et al., 1999, and references therein). In this study, it is regarded as an integral part of the Wilhelmøya Subgroup in line with Mørk et al. (1999). Phosphate and siderite-cemented glauconitic deposits observed immediately above the uppermost phosphorite conglomerates of the Wilhelmøya Subgroup in the Longyearbyen $\mathrm{CO}_{2} \mathrm{Lab}$ wells are considered to represent lateral equivalents to the Marhøgda Bed (Bäckström \& Nagy, 1985; Mørk et al., 1999) and are included in the Agardhfjellet Formation in line with Koevoets et al. (2019) (cf., Mørk et al., 1999). Previous contributions from the Longyearbyen $\mathrm{CO}_{2}$ Lab project (e.g., Braathen et al., 2012; Mørk, 2013; Van Stappen et al., 2014) have placed these deposits within the Brentskardhaugen Bed.

\section{Data and methods}

The study area in western central Spitsbergen covers an area of approximately $1750 \mathrm{~km}^{2}$ (Fig. 1C). Detailed sedimentary logging was undertaken on drillcores from the four Longyearbyen $\mathrm{CO}_{2} \mathrm{Lab}$ wells with complete coverage of the Wilhelmøya Subgroup (DH2, DH4, DH5R and DH7A; Figs. 1 \& 2). Complementary studies were conducted at outcrops exposing the targeted 
strata at the southern shore of Sassenfjorden $15 \mathrm{~km}$ to the northeast, and at Festningen $40-45 \mathrm{~km}$ west of the drill sites, respectively (Fig. 1). Observations and measurements included lithology, thickness, grain size, sorting, sedimentary structures, trace fossils and bed boundaries, and formed the basis for identification of sedimentary facies. Genetically related sedimentary facies were grouped into facies associations, interpreted to represent distinct depositional environments. A suite of wireline logs from $\mathrm{DH} 4$, including natural gamma, caliper, velocity, resistivity and qualitative density (Elvebakk, 2010), was used to further constrain the interpretations and as an aid in the recognition of sequence-stratigraphic surfaces.

\section{Palynological analysis}

A total of 33 samples from DH2 and DH4, and one sample from Festningen were analysed for palynomorphs to support dating and to provide a framework for sequence delineation and correlation between subsurface and outcrop sections. Preparation of samples was carried out by APT (Applied Petroleum Technology AS, Kjeller, Norway) using standard palynological processing techniques involving hydrochloric acid $(\mathrm{HCl})$, hydrofluoric acid (HF), potassium hydroxide $(\mathrm{KOH})$ treatment and sieving. Qualitative analysis recorded all identifiable species, and quantitative assemblage composition was considered for samples producing counts of 100 or more specimens. Thirteen samples proved barren or too poor to offer any stratigraphic control. Samples which proved productive were referred to palynological composite assemblage zones described below. Interpretations of age and stratigraphy were based on comparison with results from other localities in Svalbard (e.g., Bjærke \& Dypvik, 1977; Bjærke \& Manum, 1977; Bjærke, 1980a, b; Dypvik et al., 1985; Vigran et al., 2014; Paterson \& Mangerud, 2015).

\section{Palynological composite assemblage zones}

Based on observations made during this study, ongoing studies in eastern Spitsbergen (Rismyhr et al., unpublished data), and a series of previous studies (Orbell, 1973; Smith, 1974; Smith et al., 1975; Bjærke, 1977; Bjærke \& Dypvik, 1977; Bjærke \& Manum, 1977; Lund, 1977; Bjærke, 1980a, b; Smith, 1982; Below, 1987a, b; Fiksdal, 1988; Smelror, 1988; Hochuli et al., 1989; Smelror \& Below, 1992; Nagy et al., 2011; Ask, 2013; Lord et al., 2014; Vigran et al., 2014; Paterson \& Mangerud, 2015), ten composite assemblage zones (CAZ) covering the Late Carnian-Callovian interval in Svalbard have been defined (Fig. 3), of which 7 relevant for this study are described below in ascending order.

Leschikisporis aduncus CAZ (Late Carnian): The L. aduncus CAZ is characterised by the dominance of
Leschikisporis aduncus, Dictyophyllidites mortonii and occasionally Schizaeoisporites worsleyi. Other elements produced by the local vegetation include Deltoidospora spp., Calamospora spp., Camarozonosporites rudis, Conbaculatisporites spp., Duplexisporites problematicus, Annulispora folliculosa and Zebrasporites interscriptus. Increased diversity and representation of bisaccate pollen and Ovalipollis spp. may occur where palynomorphs were brought in by rivers, sourced by upland vegetation. In places, the freshwater alga Botryococcus may dominate, representing back barrier lagoonal facies or delta plain lakes. Rare acritarchs, represented by Micrhystridium spp. and Veryhachium spp., may also occur in these environments. The L. aduncus CAZ is equivalent to the L. aduncus assemblage described from the De Geerdalen Formation on Hopen by Paterson \& Mangerud (2015) and suggested to be of Late Carnian age.

Protodiploxipinus ornatus CAZ (latest Carnian?earliest Norian): Most of the species present in the underlying L. aduncus CAZ continue up into the $P$. ornatus CAZ. L. aduncus is, however, strongly reduced, whereas the representation of the more regional vegetation is increased with consistently higher diversity. The increased occurrence of conifer pollen, especially Protodiploxipinus spp. (P. ornatus, P. minor) is distinct (Hochuli et al., 1989; Lord et al., 2014; Paterson \& Mangerud, 2015). Rare, but persistent Micrhystridium spp. and Veryhachium spp. are present, and the green alga Plaesiodictyon moesellaneum locally becomes abundant (e.g., Lord et al., 2014; Paterson \& Mangerud, 2015). The P. ornatus CAZ is equivalent to the Protodiploxipinus spp. assemblage described by Paterson \& Mangerud (2015) from the Hopen Member of the De Geerdalen Formation on Hopen and was suggested to be of latest Carnianearliest Norian age.

Rhaetogonyaulax arctica CAZ (Early Norian): The $R$. arctica CAZ is characterised by small dinoflagellates referred to the Rhaetogonyaulax arctica (previously Shublikodinium armatum) and abundant Micrhystridium spp. Some of the spore and pollen species characteristic of underlying units are absent, whereas spores which become typical for zones above make their first appearance (Paterson \& Mangerud, 2015). The R. arctica CAZ compares with the Early Norian Classopollis torosus assemblage of Paterson \& Mangerud (2015) recognised at the base of the Flatsalen Formation (Wilhelmøya Subgroup) on Hopen, which is characterised by the first occurrence of Classopollis torosus and the first common occurrence of microforaminiferal test linings, and based on a change in terrestrial species across the boundary between the De Geerdalen Formation and the Flatsalen Formation of the Wilhelmøya Subgroup.

Heibergella CAZ (Early Norian): Samples attributed to the Heibergella CAZ commonly show rich and diverse palynomorph assemblages (Bjærke \& Manum, 1977; Vigran et al., 2014; Paterson \& Mangerud, 2015). 


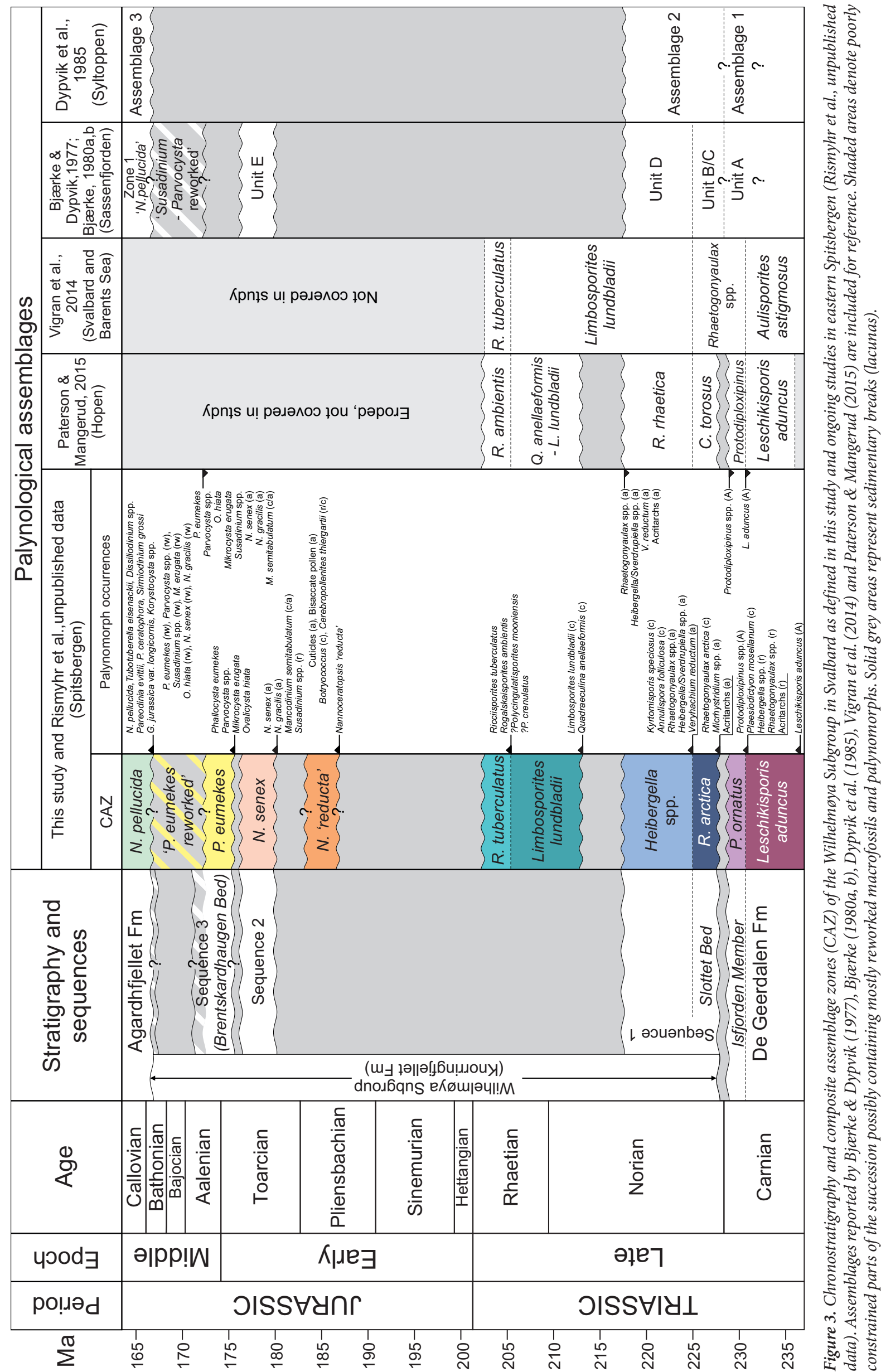


The marine component is represented by rare to superabundant occurrences of dinoflagellates belonging to the Heibergella/Sverdrupiella/Rhaetogonyaulax complex and the acritarch Veryhachium reductum. The most characteristic spore species are Kyrtomisporis speciosus and Annulispora folliculosa. In addition, common Deltoidospora spp. and many distinct spore and pollen species are present. The Heibergella CAZ is equivalent to the $R$. rhaetica assemblage of Paterson \& Mangerud (2015) recognised in deposits of the Flatsalen Formation on Hopen. An early Norian age for this assemblage is well constrained by the presence of bivalves and sirenitid ammonoids assigned to the kerri ammonoid Zone (Korčinskaya, 1980; Smith, 1982) and further corroborated by geomagnetic polarity data (Lord et al., 2014).

\section{Nannoceratopsis senex CAZ (Early-Middle} Toarcian): This composite assemblage zone is defined by abundant to superabundant occurrences of the dinoflagellates Nannoceratopsis senex, N. gracilis and Mancodinium semitabulatum. A low diversity spore and pollen assemblage - locally including occurrences of Ischyosporites variegatus and Sestrosporites pseudoalveolatus - is associated with these species. On the Norwegian Continental Shelf (NCS) and adjacent areas, abundant $N$. gracilis, N. senex and $M$. semitabulatum are known to appear at the start of a Late Pliensbachian transgression which led up to a regional Early Toarcian flooding event. This flooding event carries a characteristic sphaeromorph acritarch assemblage (e.g., Pedersen et al., 1989; Riding \& Thomas, 1992; Sawyer \& Keegan, 1996; Koppelhus \& Dam, 2003) which has not been observed in Svalbard. A second additional transgressive pulse is recognised within Lower Toarcian deposits on the NCS, also carrying similar assemblages. In eastern Spitsbergen, the N. senex CAZ have been independently dated by ammonites (Zygodactylioceras braunianus, Porpoceras polare; Rismyhr et al., unpublished data) with ranges spanning the bifrons to thouarsense ammonite biozones, indicating an Early-Middle Toarcian age for the N. senex CAZ. This corresponds to the second transgressive pulse in the Toarcian when comparing with the NCS stratigraphy.

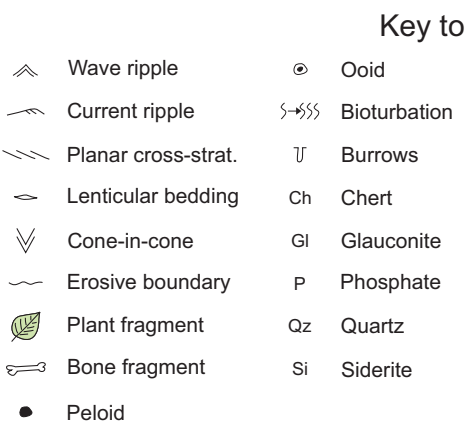

Key to sedimentary logs

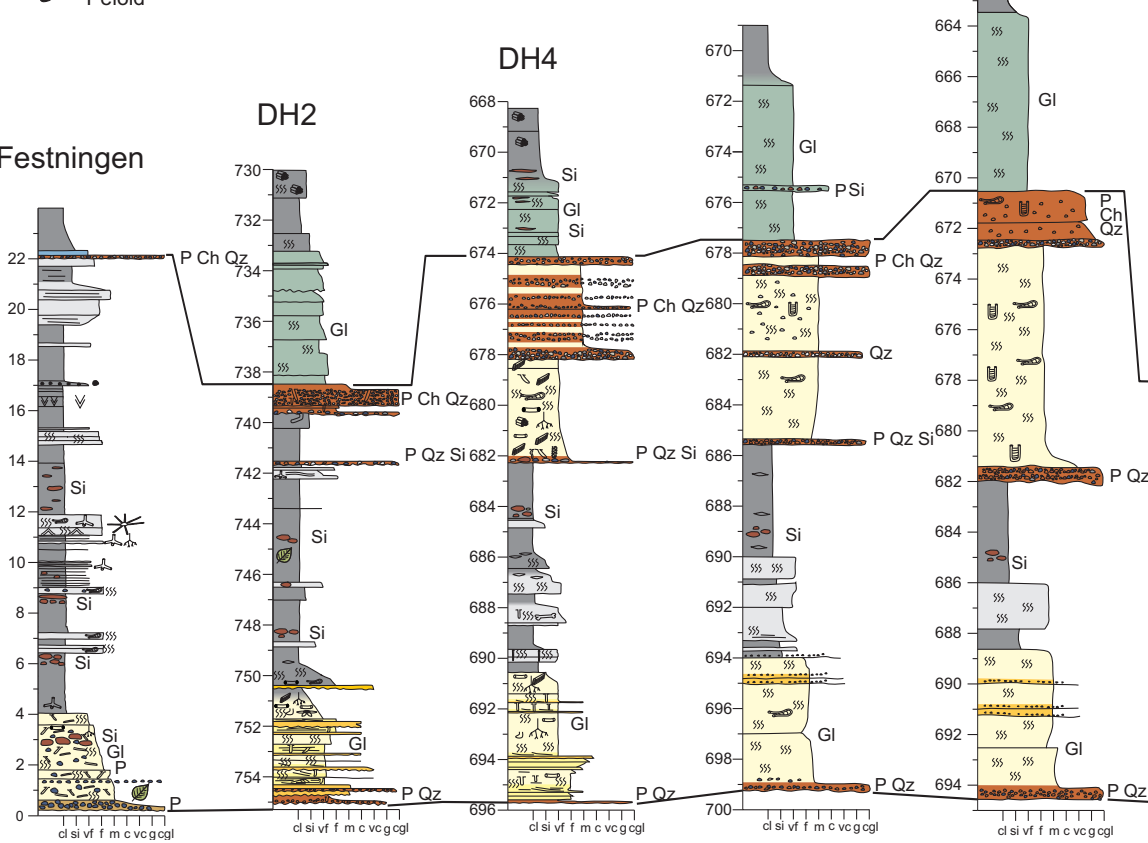

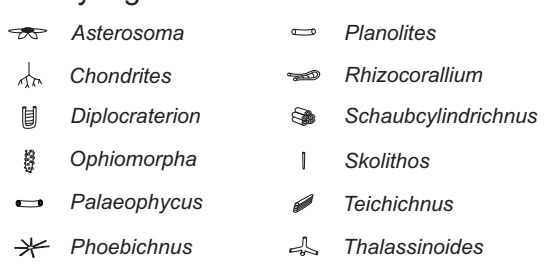

2) Phycosiphon

\& Thalassinoides

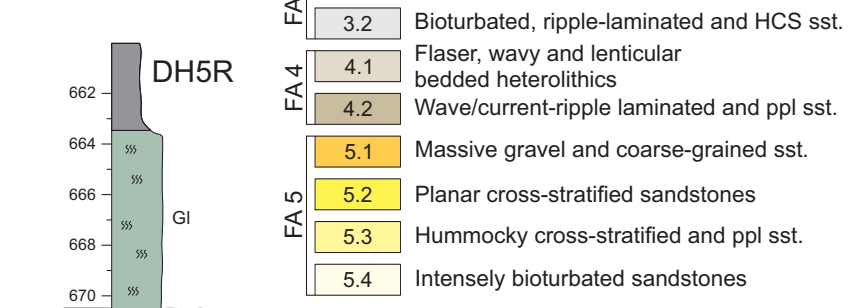

Konusdalen Marhøgda

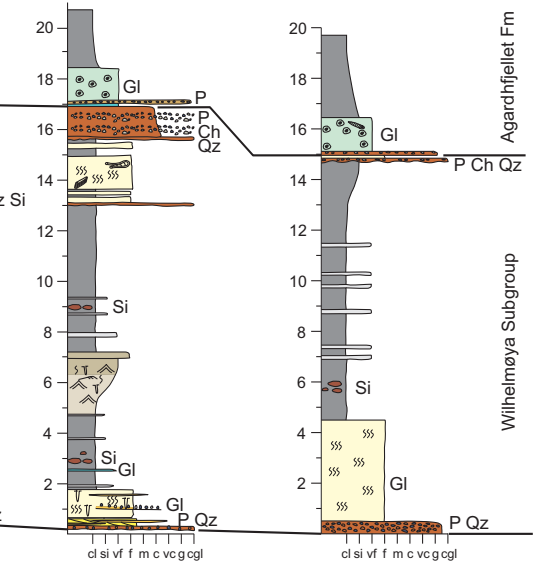

Figure 4. Facies of the Wilhelmøya Subgroup in cores and outcrops in western and central Spitsbergen. Depths and thicknesses in metres. The Marhøgda section is redrawn from Bäckström \& Nagy (1985). Abbreviations: HCS - Hummocky cross-stratified, ppl-plane-parallel laminated, sst - sandstone. 
Phallocysta eumekes CAZ (Late Toarcian-Early Aalenian): The $P$. eumekes CAZ is defined by the appearance of a number of characteristic dinoflagellate species including P. eumekes, Parvocysta spp. (e.g., P. bullula, P. barbata, P. nasuta), Ovalicysta hiata, Microcysta erugata and Susadinium spp., and Scriniocassis weberi. N. gracilis, $N$. senex and M. semitabulatum continue to be common throughout this zone. The assemblage is known from phosphate nodules of the Brentskardhaugen Bed in Spitsbergen (Bjærke, 1980a; Below, 1987a, b) where it occurs together with mid-Toarcian-Aalenian ammonites (e.g., Birkenmajer \& Pugaczewska, 1975; Pčelina, 1980; Wierzbowski et al., 1981; Bäckström \& Nagy, 1985). Comparable palynomorph assemblages have also been recorded from the Kongsøya Formation (Wilhelmøya Subgroup) on Kong Karls Land (Fiksdal, 1988; Smelror, 1988). The P. eumekes CAZ compares with the Microcysta erugata taxa range-zone and Dodekovia bullula-Nannoceratopsis senex concurrent range-zone of Smelror \& Below (1992) which were suggested to be of ?Middle to Late Toarcian and Aalenian-Early Bajocian age, respectively. The presence of $P$. eumekes together with species of the 'Parvocysta-suite' of Riding (1984) indicates a Late Toarcian-Early Aalenian age for the $P$. eumekes CAZ (e.g., Riding \& Thomas, 1992; Poulsen \& Riding, 2003).

Nannoceratopsis pellucida CAZ (Late BathonianCallovian): In the lowermost part of the Agardhfjellet Formation on Spitsbergen diverse dinoflagellate cyst assemblages appear including $N$. pellucida, Dissiliodinium spp., Tubotuberella eisenackii, Korystocysta spp., Pareodinia ceratophora, P. evittii, Sirmiodinium grossii, Sentusidinium spp. and G. jurassica subsp. adecta var. longicornis (Bjærke, 1980b; Dypvik et al., 1985). Ammonites of the Arcticoceras, Cadoceras and Kepplerites genera which have been reported from the same stratigraphic levels indicate a Late BathonianCallovian age for the lowermost Agardhfjellet Formation (e.g., Løfaldi \& Nagy, 1980; Kopik \& Wierzbowski, 1988; Koevoets et al., 2016). According to Smelror \& Below (1992), G. jurassica subsp. adecta var. longicornis and T. eisenackii first occur in upper Callovian deposits in the Barents shelf region and the N. pellucida CAZ is suggested to span the Late Bathonian-Callovian.

\section{Results}

\section{Sedimentary facies and facies associations}

From the analysis of core and outcrop data, 13 sedimentary facies were defined within the Wilhelmøya Subgroup and the lowermost Agardhfjellet Formation (Fig. 4). These were subsequently grouped into five facies associations (FA 1-5). Sedimentary facies, facies associations and their characteristics are summarised in Table 1. More comprehensive description and interpretation are presented in the following paragraphs. The facies interpretations are largely consistent with previous studies from western and central Spitsbergen (Bjærke \& Dypvik, 1977; Pčelina, 1980; Dypvik et al., 1985; Nagy \& Berge, 2008; Nagy et al., 2011).

\section{Lag deposits (FA 1)}

Description: FA 1 (Fig. 5) includes two conglomeratic facies (Facies 1.1. and 1.2; Table 1) observed at the base of the Slottet Bed, Sequence 2 (see below), and within the Brentskardhaugen Bed where it locally forms distinct strata separating sandstones of FA 5. Individual beds of FA 1 have erosional bases and sharp or gradational upper boundaries towards FA 2, FA 3 and FA 5. Facies 1.1 consists of monomictic clast-supported conglomerates with well-rounded phosphate nodules. The nodules are up to $5 \mathrm{~cm}$ in diameter and form tabular or lenticular beds up to $25 \mathrm{~cm}$ thick. Facies 1.2 consists of $\mathrm{cm}$-scale to $1 \mathrm{~m}$-thick beds of polymictic conglomerates with well-rounded chert, quartz, quartzite, and occasional siderite pebbles and subangular to rounded sandstone clasts and phosphate nodules in an intensely bioturbated (Rhizocorallium and Diplocraterion) fine- to coarsegrained sandstone matrix with scattered glauconite. The matrix weathers distinctly yellow, orange and rusty red in outcrop, but is more commonly grey in freshly exposed surfaces and in core. The phosphate nodules of the Brentskardhaugen Bed are rich in macrofossils (e.g., ammonites, bivalves, brachiopods, belemnites, etc.) which span several faunal zones of the Toarcian-Aalenian (Birkenmajer \& Pugaczewska, 1975; Wierzbowski et al., 1981; Bäckström \& Nagy, 1985).

Interpretation: The presence of marine trace fossils and scattered (?parautochthonous) glauconite with the conglomerate matrix suggests a marine depositional environment. The stratigraphic position of FA 1, resting on distinct erosion surfaces and below marine mudstones and sandstones, suggests that FA 1 accumulated mainly as lags formed by wave reworking and winnowing of underlying substrates during relative sea-level rise and shoreline transgression (e.g., Cattaneo \& Steel, 2003). The clast composition of the polymictic conglomerates indicates a mix of both intra- and extraformational components. The phosphate nodules probably formed by phosphatisation of biogenic skeletal remains and infilling of pore spaces between detrital grains in near-surface offshore environments during periods of low clastic sediment influx (Bäckström \& Nagy, 1985; Krajewski, 1990; Glenn et al., 1994; Föllmi, 1996). The quartzite and chert pebbles are extraformational in origin and were probably eroded from uplifted Precambrian metamorphic and crystalline basement rocks and Upper Permian cherts, respectively (Birkenmajer, 1972; Wierzbowski et al., 1981; Bäckström \& Nagy, 1985) and introduced into the basin during preceding relative sea-level falls. 

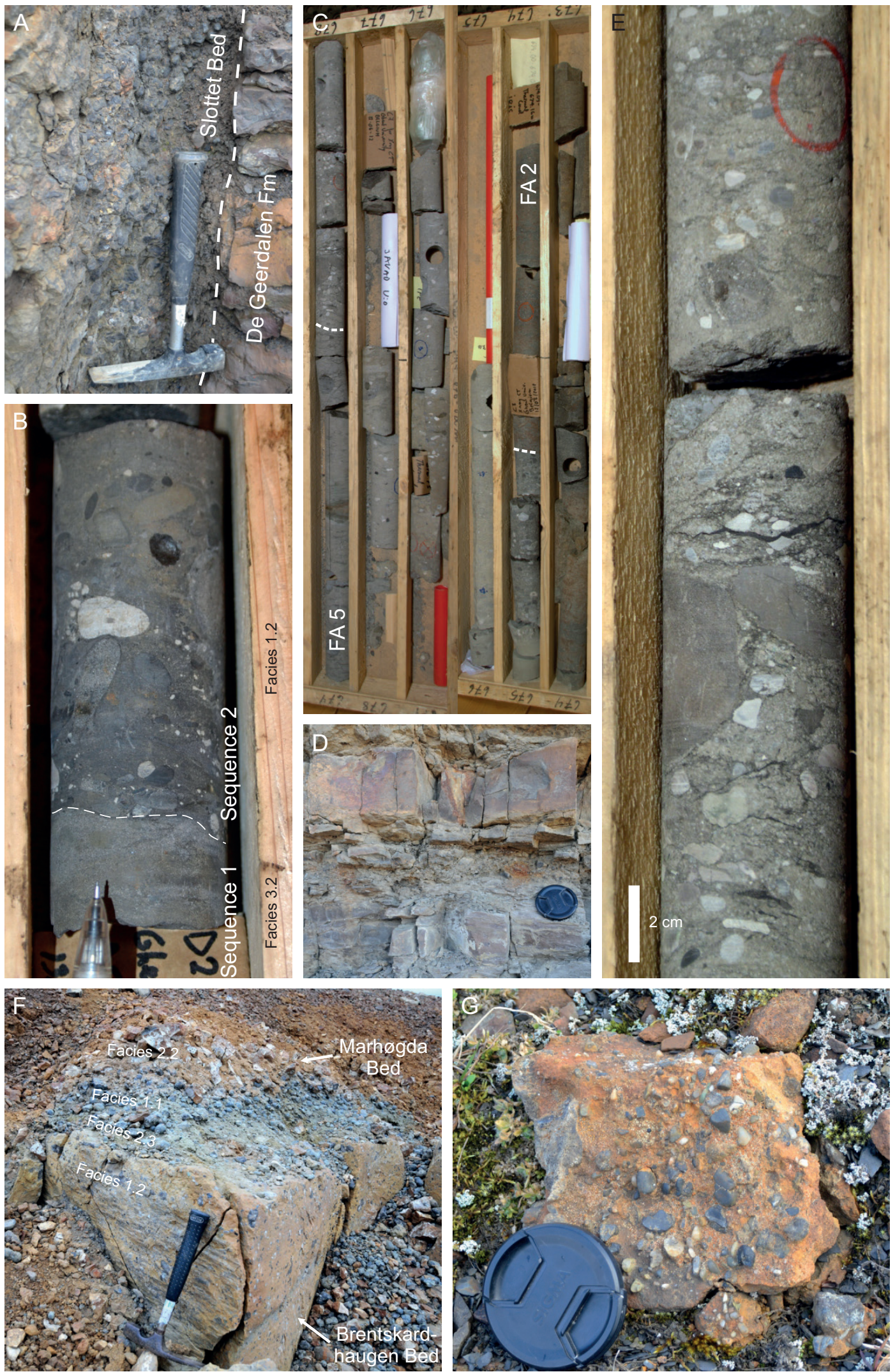

Figure 5. Examples of lag deposits (FA 1) as seen in outcrop and cores. (A) Monomictic phosphorite conglomerate (facies 1.1) at the base of the Slottet Bed at Festningen. Hammer for scale. (B) Polymictic matrix-supported conglomerate in the upper part (sequence 2) of the Wilhelmøya Subgroup in DH2. Pencil for scale. (C) FA 1 interbedded with FA 5 in the Brentskardhaugen Bed in DH4. The Brentskardhaugen Bed with sharp lower and upper boundaries towards deposits of FA 5 and FA 2, respectively. Way up from lower left to upper right. (D) Thin phosphorite conglomerate of FA 1 (above lens cap) between deposits of FA 3 below and FA 5 above in Konusdalen. Lens cap for scale. (E) Close up of (C) showing polymictic matrix-supported phosphorite conglomerates of the Brentskardhaugen Bed in DH4. The matrix is formed by fine- to medium-grained sandstones. $(F)$ and $(G)$ The Brentskardhaugen Bed in Konusdalen and Marhøgda. Hammer and lens cap for scale. Facies 2.2 and 2.3 of FA 2 are observed in $(F)$ where they form part of the Marhøgda Bed. 
Table 1. Summary of sedimentary facies and facies associations in the Wilhelmøya Subgroup in central and western Spitsbergen as observed in drillcores and outcrops. Abbreviations: BI - Bioturbation index.

\begin{tabular}{|c|c|c|c|c|c|c|c|}
\hline $\begin{array}{l}\text { Facies } \\
\text { association }\end{array}$ & Interpretation & Facies & Lithology & $\begin{array}{l}\text { Sedimentary structures, trace } \\
\text { fossils and macrofossils }\end{array}$ & BI & $\begin{array}{l}\text { Geometry, thickness, } \\
\text { boundaries }\end{array}$ & Figures \\
\hline \multirow[t]{2}{*}{ FA1 } & \multirow[t]{2}{*}{ Lag deposits } & 1.1 & $\begin{array}{l}\text { Clast-supported monomictic } \\
\text { phosphorite conglomerate. } \\
\text { Well sorted. Spherical, rounded to } \\
\text { well-rounded phosphate nodules } \\
(\text { MPS } 5 \mathrm{~cm}) \text {. }\end{array}$ & $\begin{array}{l}\text { Ammonites, bivalves, } \\
\text { belemnites and wood } \\
\text { fragments present in some } \\
\text { phosphate nodules }\end{array}$ & 0 & $\begin{array}{l}\text { Tabular and lenticular } \\
\text { beds up to } 25 \mathrm{~cm} \text { thick } \\
\text { with erosional lower } \\
\text { boundaries }\end{array}$ & $5 \mathrm{~A}, \mathrm{~F}$ \\
\hline & & 1.2 & $\begin{array}{l}\text { Polymictic matrix- and clast- } \\
\text { supported conglomerate. Poorly } \\
\text { to moderately sorted. Subangular } \\
\text { to well-rounded, subspherical to } \\
\text { oblong chert, quartz, quartzite, } \\
\text { phosphate, and siderite pebbles } \\
(\text { MPS } 10 \mathrm{~cm} \text { ) within fine- to } \\
\text { coarse-grained sandstone matrix. } \\
\text { Scattered glauconite. Normal } \\
\text { graded or massive. }\end{array}$ & $\begin{array}{l}\text { Locally low-angle cross- } \\
\text { stratification. Rhizocorallium } \\
\text { and Diplocraterion trace } \\
\text { fossils. Ammonites, bivalves, } \\
\text { belemnites and wood } \\
\text { fragments present in some } \\
\text { phosphate nodules. }\end{array}$ & $0-4$ & $\begin{array}{l}\text { Tabular beds up to } \\
40 \mathrm{~cm} \text { thick, with } \\
\text { erosional lower } \\
\text { boundaries. }\end{array}$ & $5 B-E, G$ \\
\hline \multirow[t]{3}{*}{ FA2 } & \multirow[t]{3}{*}{$\begin{array}{l}\text { Sediment- } \\
\text { starved shelf } \\
\text { deposits }\end{array}$} & 2.1 & $\begin{array}{l}\text { Brown, red and grey sandy } \\
\text { mudstone with scattered } \\
\text { glauconite and fine- to coarse- } \\
\text { grained quartz grains. Poorly } \\
\text { sorted. Siderite and phosphate } \\
\text { cemented. }\end{array}$ & $\begin{array}{l}\text { Primary sedimentary } \\
\text { structures obliterated by } \\
\text { bioturbation. }\end{array}$ & $4-6$ & $\begin{array}{l}\text { Sharp lower boundary. } \\
\text { Up to } 7 \mathrm{~m} \text { thick. }\end{array}$ & $6 \mathrm{~A}-\mathrm{D}$ \\
\hline & & 2.2 & $\begin{array}{l}\text { Glauconitic microsparitic } \\
\text { mudstone and limestone. Rare } \\
\text { quartz and chert grains, scattered } \\
\text { chamosite and phosphatic ooids. } \\
\text { Weathers red, light grey and white } \\
\text { in outcrop. }\end{array}$ & Structureless & $0-1$ & $\begin{array}{l}\text { Tabular with relatively } \\
\text { sharp lower and upper } \\
\text { boundaries. } 0.2-1.5 \mathrm{~m} \\
\text { thick. }\end{array}$ & $5 \mathrm{~F}$ \\
\hline & & 2.3 & Green, unconsolidated glauconite. & Structureless & 0 & $\begin{array}{l}\text { Apparently tabular } \\
0.1-0.3 \mathrm{~m} \text {-thick beds, } \\
\text { indistinct boundaries. }\end{array}$ & $5 \mathrm{~F}$ \\
\hline \multirow[t]{2}{*}{ FA 3} & \multirow[t]{2}{*}{$\begin{array}{l}\text { Offshore } \\
\text { deposits }\end{array}$} & 3.1 & $\begin{array}{l}\text { Grey and dark grey mudstone } \\
\text { and siltstone. Red and yellow- } \\
\text { weathering carbonate (siderite) } \\
\text { concretions. Rare pyrite } \\
\text { concretions. }\end{array}$ & $\begin{array}{l}\text { Diffuse horizontal lamination. } \\
\text { Cone-in-cone structures. }\end{array}$ & $2-5$ & Laterally extensive. & $\begin{array}{l}7 \mathrm{~B} \\
\mathrm{E}-\mathrm{G}\end{array}$ \\
\hline & & 3.2 & $\begin{array}{l}\text { Grey and reddish-purple fine- } \\
\text { and very fine-grained sandstone. } \\
\text { Normal-graded or massive. }\end{array}$ & $\begin{array}{l}\text { Wave ripples and low-angle } \\
\text { cross-lamination. Intense } \\
\text { bioturbation with Chondrites, } \\
\text { Palaeophycus, Phoebichnus } \\
\text { trochoides, Rhizocorallium } \\
\text { and Thalassinoides. Rare } \\
\text { bone-fragments. }\end{array}$ & $4-6$ & $\begin{array}{l}\text { Tabular beds up to } \\
0.05-0.8 \mathrm{~m} \text { thick with } \\
\text { sharp lower and abrupt } \\
\text { or gradational upper } \\
\text { boundaries. }\end{array}$ & $\begin{array}{l}\text { 7A, } \\
\mathrm{C}-\mathrm{F} \\
\mathrm{H}\end{array}$ \\
\hline \multirow[t]{2}{*}{ FA 4} & \multirow[t]{2}{*}{$\begin{array}{l}\text { Prodelta and } \\
\text { distal delta } \\
\text { front deposits }\end{array}$} & 4.1 & $\begin{array}{l}\text { Mudstone, siltstone and } \\
\text { very fine-grained sandstone. } \\
\text { Upward-coarsening. }\end{array}$ & $\begin{array}{l}\text { Lenticular, wavy and flaser } \\
\text { lamination. Wave- and current } \\
\text { ripples observed in sandstones. } \\
\text { Rare Planolites traces. }\end{array}$ & $1-3$ & $\begin{array}{l}\text { Gradational lower and } \\
\text { upper boundaries. }\end{array}$ & $\begin{array}{c}8 \mathrm{~A} \\
\mathrm{~B}\end{array}$ \\
\hline & & 4.2 & $\begin{array}{l}\text { Pale yellow and light grey very } \\
\text { fine- to fine-grained sandstone. }\end{array}$ & $\begin{array}{l}\text { Wave- and current ripples. } \\
\text { Plane-parallel lamination. } \\
\text { Rare Skolithos. }\end{array}$ & $1-5$ & $\begin{array}{l}\text { Tabular. Gradational } \\
\text { lower and sharp upper } \\
\text { boundaries. }\end{array}$ & $8 \mathrm{~A}$ \\
\hline \multirow[t]{4}{*}{ FA 5} & \multirow[t]{4}{*}{$\begin{array}{l}\text { Shoreface } \\
\text { deposits }\end{array}$} & 5.1 & $\begin{array}{l}\text { Gravel, very coarse- and coarse- } \\
\text { grained sandstone. Poorly to } \\
\text { moderately sorted. Massive or } \\
\text { upward-fining. }\end{array}$ & Structureless & 0 & $\begin{array}{l}\text { Laterally discontinuous, } \\
\text { lenticular to apparently } \\
\text { tabular beds up to } \\
20-25 \mathrm{~cm} \text { thick. Erosive } \\
\text { lower boundaries. }\end{array}$ & $\begin{array}{l}9 \mathrm{~A} \\
\mathrm{~B}, \mathrm{E}\end{array}$ \\
\hline & & 5.2 & $\begin{array}{l}\text { Fine-grained sandstone. } \\
\text { Weathers yellow. }\end{array}$ & Planar cross-stratification. & $1-3$ & $\begin{array}{l}\text { Laterally extensive. } \\
\text { Gradational or sharp } \\
\text { boundaries. }\end{array}$ & \\
\hline & & 5.3 & $\begin{array}{l}\text { Very fine- and fine-grained, } \\
\text { light grey sandstone. }\end{array}$ & $\begin{array}{l}\text { Diffuse to well-defined plane- } \\
\text { parallel and low-angle cross- } \\
\text { lamination locally resembling } \\
\text { hummocky cross-stratification. }\end{array}$ & $1-2$ & $\begin{array}{l}\text { Gradational or sharp } \\
\text { boundaries. }\end{array}$ & 9A, E, G \\
\hline & & 5.4 & $\begin{array}{l}\text { Medium- to very fine-grained } \\
\text { sandstones with scattered } \\
\text { glauconite and variable amounts } \\
\text { of dispersed mud. Well-sorted. } \\
\text { Rare phosphate nodules. }\end{array}$ & $\begin{array}{l}\text { Intensely bioturbated } \\
\text { containing Asterosoma, } \\
\text { Chondrites, Cylindrichnus, } \\
\text { Diplocraterion, ?Ophiomorpha, } \\
\text { Palaeophycus, Phycosiphon, } \\
\text { Planolites, Rhizocorallium, } \\
\text { Schaubcylindrichnus, Skolithos } \\
\text { and Teichichnus. }\end{array}$ & $4-6$ & $\begin{array}{l}\text { Tabular. Up to } 8 \mathrm{~m} \\
\text { thick. Gradational or } \\
\text { sharp boundaries. }\end{array}$ & $9 \mathrm{~A}-\mathrm{F}$ \\
\hline
\end{tabular}



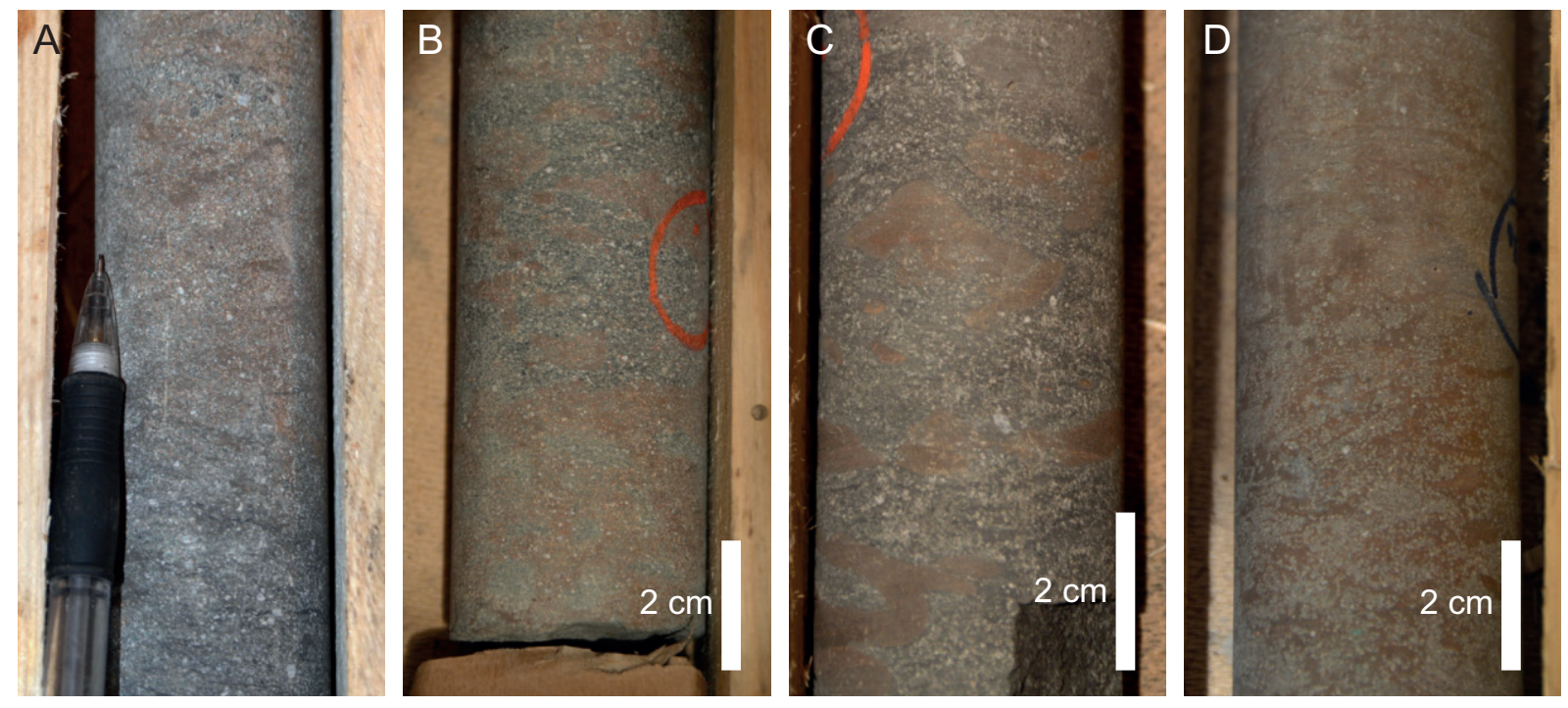

Figure 6. Siderite and phosphate-cemented, poorly sorted, sandy mudstones of facies 2.1 with scattered glauconite and quartz grains in DH4. Note the increasing degree of cementation upward from (A) (lowest) to (D) (highest).

\section{Sediment-starved shelf deposits (FA 2)}

Description: Deposits of FA 2 (Figs. 5F \& 6) are ubiquitous at the base of the Agardhfjellet Formation and are locally observed in the lower part of the Wilhelmøya Subgroup above the Slottet Bed. Three facies are included in FA 2 (Facies 2.1-2.3; Table 1), all characterised by relatively high, but varying amounts of green and dark green glauconitic grains. Deposits of Facies 2.1 sharply overlie the Brentskardhaugen Bed in all investigated drillcores and form composite bodies up to $7 \mathrm{~m}$ thick which grade upward into dark grey mudstones. They consist of phosphate- and siderite-cemented (Mørk, 2013) grey, brown and red, poorly sorted, glauconitic muddy sandstones/sandy mudstones with scattered fineto coarse-grained quartz grains. Internal stratification is poorly defined due to the intense bioturbation, but individual beds locally appear to fine slightly upward. Facies 2.2 occurs at the same stratigraphic level in outcrops at Festningen, Konusdalen and Marhøgda and consists of $0.2-1.5$ m-thick tabular beds of partially sideritised and dolomitised microsparitic limestone, locally containing scattered belemnites, ferruginous ooids, quartz, chert and phosphate grains. These deposits correspond to the Marhøgda Bed as originally defined by Bäckström \& Nagy (1985). Facies 2.3 is encountered above the Slottet Bed and at the interface between the Brentskardhaugen Bed and the Marhøgda Bed in Konusdalen and 'Criocerasdalen', and consists of 0.1 to $0.3 \mathrm{~m}$-thick poorly consolidated beds apparently composed entirely of glauconitic grains (i.e., glaucony sensu Odin \& Matter, 1981).

Interpretation: Based on the abundance of glauconite, the stratigraphic affiliation with FA 1 and FA 3, and intense bioturbation, FA 2 is interpreted to have accumulated on a sediment-starved offshore shelf. This is supported by the presence of carbonate- and iron-rich deposits which similarly point toward a relatively low clastic sediment influx (Macquaker et al., 1996). Autochthonous glauconite is generally regarded as a good indicator of low sedimentation rates in marine deposits and is most commonly developed during transgressive stages (Odin \& Matter, 1981; Amorosi, 2012). Periodic storms and elevated energy levels may be indicated by the intermixed fine to coarse quartz grains observed in Facies 2.1.

\section{Offshore deposits (FA 3)}

Description: FA 3 (Fig. 7) is observed above the Slottet Bed in the Wilhelmøya Subgroup and above the Marhøgda Bed in the Agardhfjellet Formation in all drillcores and outcrops. Two facies (Facies 3.1 and 3.2; Table 1) are defined in FA 3, together forming successions up to $15 \mathrm{~m}$ thick within the studied interval. Facies 3.1 consists of massive to diffusely laminated, grey and dark grey silty mudstones. Moderate bioturbation is observed in the siltier horizons. Lenticular, yellow- and red-weathering carbonate (e.g., siderite) nodules are common and concentrate in discrete horizons, locally coalescing to form nearly continuous beds. Cone-in-cone structures are locally observed.

Facies 3.2 consists of sharp-based, 0.05-0.8 m-thick, tabular very fine- to fine-grained sandstones. The sandstones are massive or fine upward into mudstones of Facies 3.1. The sandstones are commonly grey to dark grey in colour but may weather distinctly reddishpurple in outcrop when cemented by siderite. The degree of bioturbation is persistently high with ichnofossils including Chondrites, Palaeophycus, Thalassinoides and Skolithos. Relatively large Phoebichnus trochoides (see also Bromley \& Mørk, 2000) and Rhizocorallium irregulare 

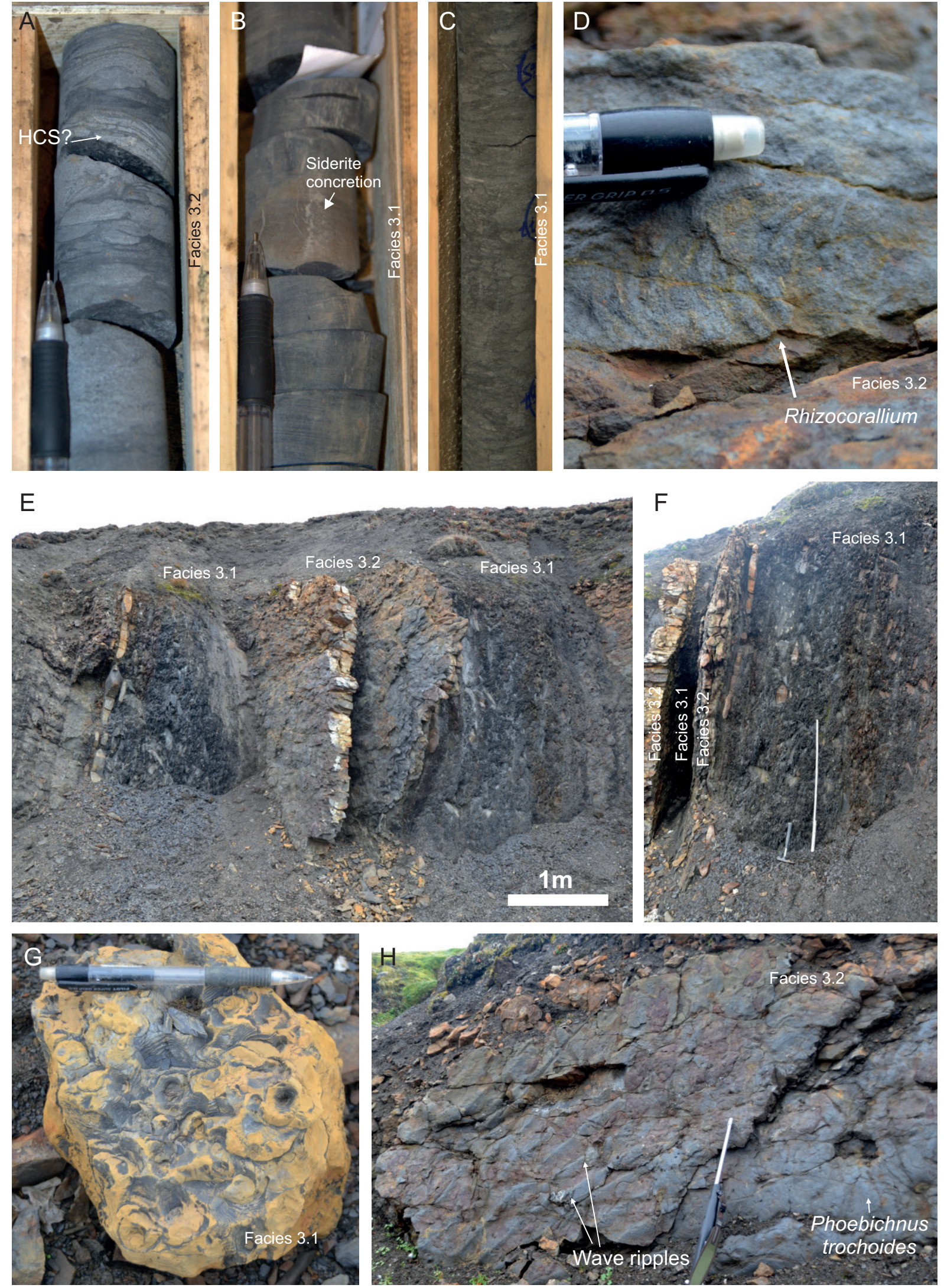

Figure 7. Representative photos of FA 3 in core and outcrop. (A) Thin-bedded sandstones of Facies 3.2 with massive to low-angle crosslaminated, possibly hummocky cross-stratified bases and bioturbated silty tops, DH2. Pencil for scale. (B) Structureless mudstone (Facies 3.1) with siderite concretions, DH2. Pencil for scale. (C) Bioturbated silty sandstone (Facies 3.2) in DH4. (D) Rhizocorallium on bed surface of facies 3.2, Festningen. Pencil for scale. (E) and (F) FA 3 at Festningen showing massive to diffusely laminated mudstones and siltstones (Facies 3.1) interbedded with thin, heavily cemented sandstones (Facies 3.2). (G) Cone-in-cone structure in carbonate bed, Festningen. (H) Top surface of sandstone bed of Facies 3.2 with well-defined wave-ripples and large Phoebichnus trochoides trace at Festningen. Rifle for scale. Abbreviations: HCS - Hummocky cross-stratification. 

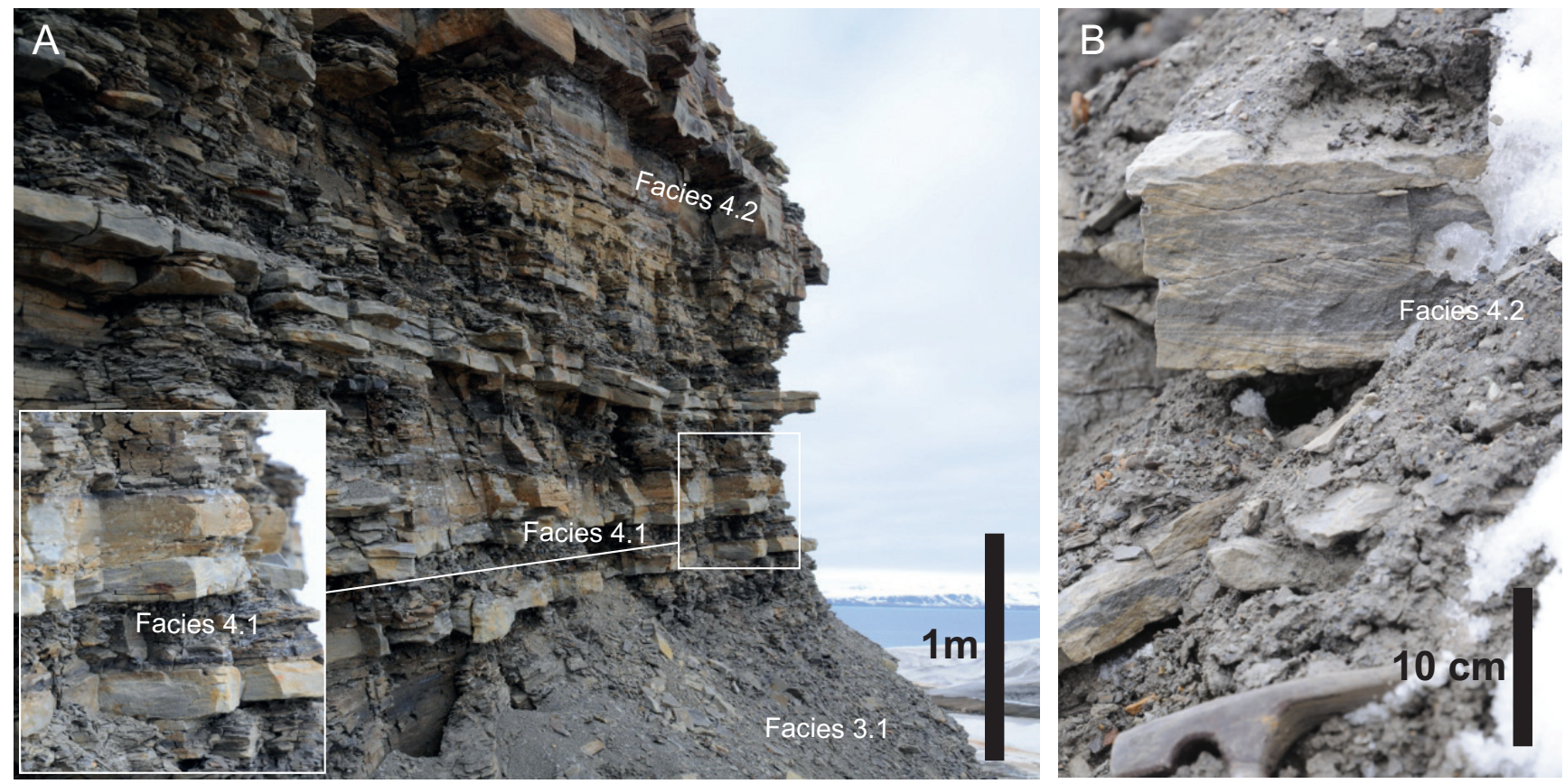

Figure 8. Examples of FA 4 in outcrop. (A) Upward-coarsening unit consisting of interbedded heterolithics (Facies 4.1) at the base grading upward into wave ripple-, current ripple- and plane-parallel laminated sandstones (Facies 4.2) in Konusdalen. (B) Current ripple-laminated sandstone (Facies 4.1) within the lower heterolithic part of an upward-coarsening unit in 'Criocerasdalen'.

traces are observed on some of the bed surfaces at Festningen. Primary sedimentary structures within the sandstones are scarce due to the intense bioturbation, but wave ripples and plane-parallel to low-angle crosslamination are locally observed. A single bone fragment was encountered in $\mathrm{DH} 4$.

Interpretation: Based on the dominance of mudstones and siltstones, the presence of wave ripples and a marine trace fossil assemblage which compares with a proximal expression of the Cruziana ichnofacies (Maceachern et al., 2007), deposits of FA 3 are interpreted to have accumulated below fair-weather wave base in an offshore environment. The mudstones and siltstones of Facies 3.1 were probably deposited as suspension fallout during fair-weather sedimentation. The sandstones of Facies 3.2 are interpreted as storm beds formed by redeposition of sand delivered offshore by flooding rivers or scour of an adjacent shoreface or delta front by storm waves. The upward-fining character of some of these sandstones reflects waning of storm waves followed by fairweather sedimentation and intense burrowing (Dott \& Bourgeois, 1982). The local presence of carbonates may indicate relatively low rates of clastic sedimentation. This is supported by the occurrence of the trace fossil Phoebichnus trochoides which is thought to require extended periods of slow sedimentation in low-energy marine environments to form its large and complicated structure (Heinberg \& Birkelund, 1984; Bromley \& Mørk, 2000).

\section{Prodelta and distal delta-front deposits (FA 4)}

Description: FA 4 (Fig. 8) features deposits observed locally in the lower part of the Wilhelmøya Subgroup in Konusdalen and 'Criocerasdalen', where they form 1-3 m-thick, sheet-like, coarsening-upward (CU) units with gradational bases and abrupt tops towards FA 3 . Two facies (Facies 4.1 and 4.2; Table 1) are included in FA 4. Facies 4.1 forms the lower part of the CU-units and comprises lenticular-, wavy- and flaser-laminated heterolithic deposits. Current- and wave-ripples are observed in some of the interbedded sandstones. The degree of bioturbation is low to moderate and only Planolites is observed. Facies 4.1 grades upward into Facies 4.2 consisting of tabular very fine- to fine-grained sandstones up to $20 \mathrm{~cm}$ thick. The sandstones are pale yellow to light grey in colour and contain plane-parallel lamination and common wave- and current ripples, locally with flattened ripple crests. Skolithos traces are locally observed.

Interpretation: Based on the vertical association with fully marine offshore deposits of FA 3, the heterolithic upward-coarsening motif, and the co-occurrence of wave- and current ripples, FA 4 is interpreted as a progradational prodelta to distal lower delta-front succession. This is supported by the absence of similar units within drillcores and nearby outcrops which suggests that FA 4 is of restricted areal extent consistent with a sediment point source. Plane-parallel and rippled sandstones are interpreted to reflect fair-weather wavereworking of distal river-fed hyperpycnal flows (Mulder 

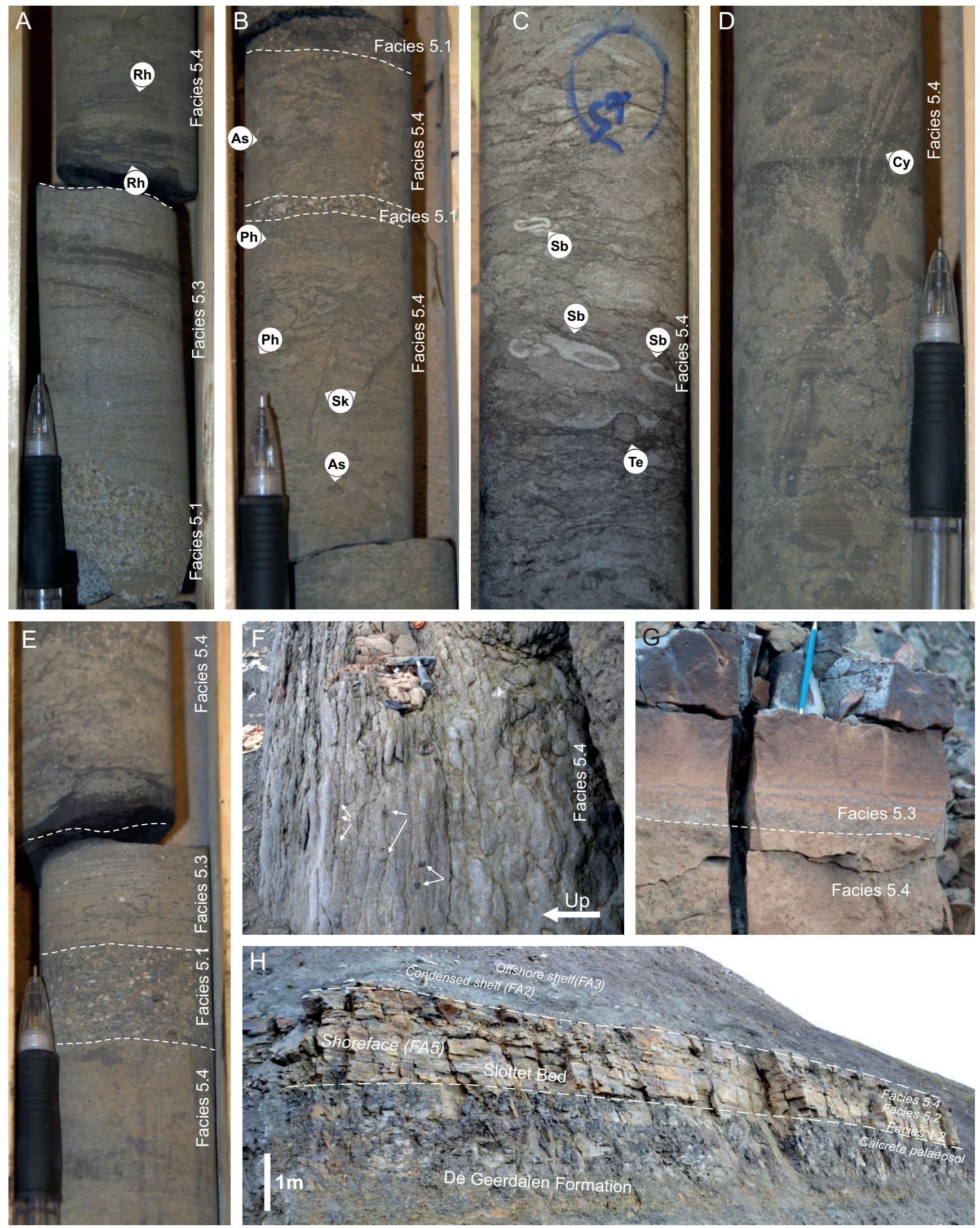

Figure 9. Examples of shoreface deposits (FA 5) in outcrop and core. (A) Coarse- to very coarse-grained sandstone (Facies 5.1) overlain by low-angle cross-stratified (Facies 5.3) and bioturbated very fine-grained sandstone (Facies 5.4), Slottet Bed in DH2. (B) Bioturbated sandstone (Facies 5.4) with pockets of coarse-grained sandstone (Facies 5.1), Slottet Bed in DH2. (C) Bioturbated sandstone (Facies 5.4) in the upper part (Sequence 2) of the Wilhelmøya Subgroup in DH4. (D) Cylindrichnus (Cy) in bioturbated sandstone (Facies 5.4), Slottet Bed in DH2. (E) Alternating Facies 5.1, 5.3 and 5.4 in the Slottet Bed in DH2. (F) Bioturbated sandstone with scattered phosphate nodules (arrows) in the Slottet Bed at Festningen. Hammer for scale. $(G)$ and $(H)$ Deposits of FA 5 in the Slottet Bed in Konusdalen. Abbreviations: As - Asterosoma, Cy Cylindrichnus, $P h$ - Phycosiphon, $R h$ - Rhizocorallium, $S b$ - Schaubcylindrichnus, $S k$ - Skolithos, $T e$ - Teichichnus. 
et al., 2003), whereas the limited bioturbation points toward environmental stress due to high freshwater input (i.e., reduced salinity levels) or increased depositional rates (Maceachern et al., 2007; Nagy \& Berge, 2008).

\section{Shoreface deposits (FA 5)}

Description: FA 5 (Fig. 9) is present in the Slottet Bed, in the upper part of the Wilhelmøya Subgroup in $\mathrm{DH} 4$, DH5R and DH7A, and locally interbedded with FA 1 in the Brentskardhaugen Bed. FA 5 includes four facies (Facies 5.1-5.4; Table 1) which form composite sandstone bodies up to $9 \mathrm{~m}$ thick. Facies 5.1 consists of poorly to well-sorted gravel, and very coarse and coarse-grained sandstones observed in the Slottet Bed. The sandstones have sharp and erosional bases, are generally up to a few cms thick and laterally discontinuous, but may locally reach more than $20 \mathrm{~cm}$ in thickness. They commonly grade upward into Facies 5.3. Facies 5.2 is locally observed near the base of the Slottet Bed in Konusdalen and consists of scarcely bioturbated, planar cross-stratified, sandstone beds up to $20 \mathrm{~cm}$ thick. Facies 5.3 is developed in the Slottet Bed in the drillcores and commonly occurs in vertical series between Facies 5.1 and 5.4. It includes light grey, very fine- to fine-grained sandstones with diffuse to well-defined plane-parallel and low-angle cross-lamination with an affinity to hummocky crossstratification. Facies 5.4 consists of intensely bioturbated medium- to very fine-grained sandstones with scattered glauconite. The sandstones are relatively well sorted with minor amounts of dispersed mud, accentuated by the bioturbation. A high diversity ichnofossil assemblage is observed in this facies comprising Asterosoma, Chondrites, Cylindrichnus, Diplocraterion, Ophiomorpha, Palaeophycus, Phycosiphon, Planolites, Rhizocorallium, Schaubcylindrichnus, Skolithos and Teichichnus.

Interpretation: The high diversity/high intensity ichnofossil assemblage compares with distal expressions of the Skolithos ichnofacies or proximal expressions of the Cruziana ichnofacies (Maceachern et al., 2007). These ichnofossil assemblages are indicative of relatively high levels of wave or current energy, and are especially common in sand-prone, marine, lower shoreface environments. The presence of possible hummocky cross-stratification supports this interpretation and suggests periodic storm influence with deposition of bedload and suspended sediment during oscillatorydominant combined flows (Dumas \& Arnott, 2006). Facies 5.1, 5.3 and 5.4 when present in a continuous vertical succession are suggested to reflect (1) rapid deposition of coarse-grained lags in scour troughs following strong storm wave erosion (Clifton, 2006), (2) waning storm phase with deposition of hummocky cross-stratified sandstones, and (3) re-establishment of fair-weather conditions allowing extensive biogenic reworking of recently emplaced storm deposits. The local presence of planar cross-stratification (Facies 5.2) reflects migration of straight-crested 2D dunes by longshore or shore-normal currents (Clifton et al., 1971; Reading and Collinson, 1996) and may represent deposition in a somewhat more proximal part of the shoreface (i.e., middle to upper shoreface).

\section{Palynological analysis}

The palynological assemblages observed in the investigated samples are referred to composite assemblage zones (CAZ) described in the Data and methods section. Interpreted ages and characteristic palynomorphs of these CAZs are listed in Fig. 3.

\section{Festningen}

A single sample from the lower part of the Wilhelmøya Subgroup at Festningen $(5.5 \mathrm{~m}$ above the base of the Subgroup; Fig. 4) was examined in the present study. The sample produced a rich assemblage dominated by dinocysts of the Heibergella/Sverdrupiella group, with abundant Veryhachium reductum and common Annulispora folliculosa. Additional palynomorphs observed include Kyrtomisporis speciosus, Camarozonosporites rudis, Classopollis harrisii, Dictyophyllidites mortonii, Stereisporites antiquasporites, Schizosporis sp. and Micrhystridium sp. The dominance of dinocysts of the Heibergella/Sverdrupiella group in association with common to abundant $V$. reductum and A. folliculosa, and rare $K$. speciosus indicate a reference to the Heibergella CAZ (Fig. 3).

\section{$\mathrm{DH} 2$}

Nineteen samples were analysed from the interval 731.5 to $757.8 \mathrm{~m} \mathrm{MD}$ in $\mathrm{DH} 2$ (Fig. 10). The samples from 731.5 to $732.5 \mathrm{~m}$ produced poorly preserved dinoflagellates including Dissiliodinium willei, Pareodinia "radiata" (informal species), Chytroeisphaeridia hyalina, Korystocysta spp., Sentusidinium spp. and Crussolia perireticulata. This assemblage is tentatively referred to the N. pellucida CAZ (Fig. 3).

Samples from the Brentskardhaugen Bed proved barren of palynomorphs. In samples immediately below (739.9 to $741.55 \mathrm{~m} \mathrm{MD}$ ), however, Nannoceratopsis senex occurs abundantly together with rare Mancodinium semitabulatum and Sestrosporites pseudoalveolatus. Sphaeromorphs are observed locally. These samples are referred to the N. senex CAZ (Fig. 3).

At $742.4 \mathrm{~m} \mathrm{MD}$ the first markers of the Heibergella CAZ appear with abundant Veryhachium reductum and Annulispora folliculosa, and rare Kyrtomisporis speciosus. Heibergella/Rhaetogonyaulax spp. are present from 744.4 $\mathrm{m} \mathrm{MD}$ and continue down to $751.1 \mathrm{~m} \mathrm{MD}$ together with 
common $V$. reductum. A distinct change in assemblage is noted at $755.2 \mathrm{~m} \mathrm{MD}$ where marine elements become strongly reduced or absent. The samples at 755.2-757.8 $\mathrm{m} \mathrm{MD}$ are characterised by Leschikisporis aduncus, Protodiploxipinus ornatus and Anapiculatisporites spiniger. Additional palynomorphs present include $P$. minor, Kyrtomisporis niger, Aratrisporites macrocavatus, Ovalipollis ovalis, Colpectopollis ellipsoideus, Dictyophyllidites mortonii and Eucommiidites cf. intrareticulatus. The common occurrence of P. ornatus at 757.8 m MD may indicate a reference to the P. ornatus CAZ.

\section{$\mathrm{DH} 4$}

Fourteen samples were taken from DH4 (Fig. 10). Samples from the Agardhfjellet Formation, the Brentskardhaugen Bed and Sequence 2 as defined below (670.8 to $681.9 \mathrm{~m} \mathrm{MD}$ ) all proved barren or consisted only of non-diagnostic elements. At 682.9 to $689.1 \mathrm{~m} \mathrm{MD}$ the appearance of rich and characteristic assemblages of the Heibergella CAZ is noted with abundant Heibergella/Sverdrupiella spp. and Deltoidospora spp., and common to abundant $V$. reductum. A. folliculosa and K. speciosus occur persistently throughout. Aratrisporites spp., Chasmatosporites sp., Dictyophyllidites spp. and Protodiploxipinus spp. may be common in some samples.

Samples from the Slottet Bed (692.0 to $695.4 \mathrm{~m} \mathrm{MD)}$ were barren of palynomorphs. A sample collected immediately below the Slottet Bed (697.0 m MD) was dominated by Deltoidospora spp., with common P. ornatus and rare Aratrisporites spp., A. spiniger, C. ellipsoideus, Dictyophyllidites spp., $K$. niger, Taeniasporites rhaeticus and Schizosporis sp.. The common occurrence of P. ornatus together with several characteristic Upper Triassic palynomorphs may indicate a reference to the P. ornatus CAZ.

\section{Discussion}

\section{Palynostratigraphic correlation}

The palynological data from $\mathrm{DH} 2$ and $\mathrm{DH} 4$ presented above have been compared with assemblages reported from other localities in Svalbard (Fig. 3; Bjærke \& Dypvik, 1977; Bjærke \& Manum, 1977; Bjærke, 1980a, b; Dypvik et al., 1985; Vigran et al., 2014; Paterson \& Mangerud, 2015).

Assemblages observed in samples from the De Geerdalen Formation in DH2 and DH4 are referred to the P. ornatus CAZ. Similar assemblages have been reported from the uppermost few metres of the Isfjorden Member of the De Geerdalen Formation at Festningen (Vigran et al.,2014) and from the Hopen Member of the De Geerdalen Formation on Hopen (Paterson \& Mangerud, 2015).
The $R$. arctica CAZ, associated with the Slottet Bed at the base of the Wilhelmøya Subgroup (Fig. 3) was not recognised in this study, probably due to non-productive samples from this sandstone-dominated stratigraphic level. Bjærke \& Dypvik (1977), however, reported rich assemblages dominated by acritarchs and dinoflagellates, including Micrhystridium spp., Veryhachium spp., Baltisphaeridium spp., Cymatiosphaera spp., Pterospermopsis sp. and Rhaetogonyaulax spp. (reported as Shublikodinium spp.) from phosphate nodules of the Slottet Bed (their Unit B) at Marhøgda. This suggests that the $R$. arctica CAZ is probably developed and present throughout the study area.

The Heibergella CAZ assemblage is recognised in both DH2 and DH4, and at Festningen. Comparable assemblages have been reported from Syltoppen (Dypvik et al., 1985; Assemblage 2), Sassenfjorden (Bjærke \& Dypvik, 1977, Unit D) and Festningen (Vigran et al., 2014). Nagy et al. (2011) presented palynomorphs from two samples collected from the lower Wilhelmøya Subgroup at the Juvdalskampen section, some 20 kilometres east of the study area. These samples were dominated by the terrestrial palynomorphs Deltoidospora minor, Chasmatosporites apertus and Kyrtomisporis speciosus but also included abundant Rhaetogonyaulax spp. and Veryhachium reductum. The same samples were reanalysed as part of a palynofacies study by Mueller et al. (2014), who also noted the presence of Heibergella asymmetrica, indicating a reference to the Heibergella CAZ.

An extensive range chart from the Festningen section covering the entire Wilhelmøya Subgroup was presented in Vigran et al. (2014, p. 84-85, tables A1.2.1 and A1.2.2). They recorded assemblages comparable with the Heibergella CAZ throughout most of the Wilhelmøya Subgroup. The boundary between the proposed Tverrbekken and Teistberget members was placed approximately in the middle of the succession (Vigran et al., 2014, p. 30, fig. 22a) in accordance with Mørk et al. (1999) and Nagy \& Berge (2008). The Tverrbekken member was dated as Norian (their Limbosporites lundbladii CAZ), while an undifferentiated Early-Middle Jurassic age was indicated for the proposed Teistberget member. This interpretation was based on the presence of rare Cleistosphaeridium sp. (observed in 5 samples) and rare Cerebropollenites thiergartii (observed in 2 samples). Cleistosphaeridium sp. has not previously been used as a marker for the Early Jurassic. C. thiergartii, however, has traditionally been regarded to have its first appearance in the Early Jurassic (e.g., Suneby \& Hills, 1988; Von Hillebrandt et al., 2007), although occurrences within the Rhaetian have also been documented (e.g., Bonis et al., 2009). The proposed Teistberget member at Festningen is otherwise completely dominated by diverse and characteristic Late Triassic elements, including the Norian dinocysts Hebecysta spp., Heibergella spp., Noricysta spp., Rhaetogonyaulax spp. and Sverdrupiella spp. (Bujak \& Fisher, 1976), terrestrial palynomorphs 

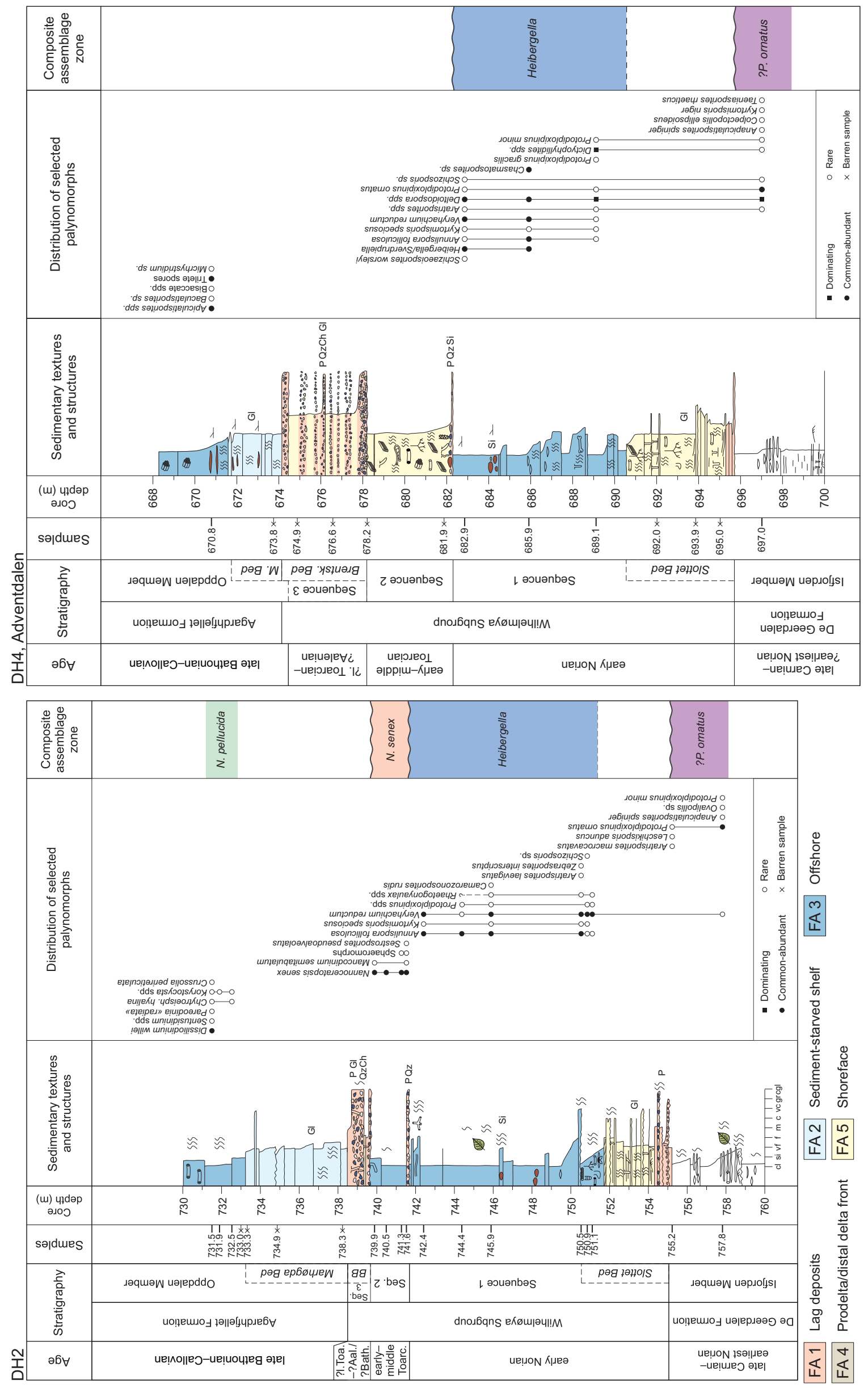
including the important marker Limbosporites lundbladii and typical Late Triassic palynomorphs including Aratrisporites spp., Camarozonosporites spp., Kyrtomisporis spp., Protodiploxipinus spp., Rogalskaisporites barentzii. These were all interpreted as reworked by Vigran et al. (2014) and relative abundances were not given. A potential diagnostic feature of the assemblages at Festningen is the occurrence of abundant Veryhachium spp. throughout both the proposed Tverrbekken and Teistberget members. Veryhachium spp. is known to occur abundantly in Norian deposits in Svalbard (Bjærke, 1977; Bjærke \& Dypvik, 1977; Dypvik et al., 1985; Vigran et al., 2014; Paterson \& Mangerud, 2015), but has not been recorded as a dominating element in Lower Jurassic deposits in the region. Elements characteristic of the Toarcian N. senex CAZ were not present in any of the samples from the Festningen section and it is therefore suggested that the entire section (excluding the Brentskardhaugen Bed) should be referred to the Early Norian $R$. arctica/Heibergella CAZs. This is supported by Pčelina (1980) and Dypvik et al. (1985) who indicated that the Brentskardhaugen Bed rests unconformably on Upper Triassic deposits in western parts of Spitsbergen.

Assemblages referred to the $N$. senex CAZ were encountered only in $\mathrm{DH} 2$ in this study. Comparable assemblages, however, were also reported from mudstones immediately below the Brentskardhaugen Bed in the Sassenfjorden area by Bjærke \& Dypvik (1977). The assemblages recorded from their Unit E were dominated by the dinoflagellate cyst Nannoceratopsis gracilis, with rare Susadinium sp. and terrestrial palynomorphs Ischyosporites variegatus and Contignisporites dunrobinensis. A sandstone unit developed at the same stratigraphic level in DH4 (681.9$678.2 \mathrm{~m} \mathrm{MD}$ ) produced only barren samples but is here tentatively suggested to correlate with the $N$. senex CAZ in DH2 along with equivalent strata in DH5R and DH7A. Smelror \& Below (1992) correlated Unit E of Bjærke \& Dypvik (1977) with their Mikrocysta erugata taxa rangezone. Unit E of Bjærke \& Dypvik (1977), and deposits in DH2 here referred to the N. senex CAZ, however, lack the marker species and several characteristic taxa of the M. erugata taxa range-zone of Smelror \& Below (1992) (including M. erugata, Phallocysta spp. and Parvocysta spp.). and the $M$. erugata taxa range-zone appears to compare more closely with the P. eumekes CAZ.

The P. eumekes CAZ was not observed in any of the samples analysed in this study, and in western central Spitsbergen has only been reported from phosphate nodules of the Brentskardhaugen Bed (Bjærke, 1980a; Below, 1987a, b). In situ occurrences of P. eumekes CAZ and associated deposits in western central Spitsbergen may therefore remain undocumented either due to unproductive samples or because it occurs only in a reworked position within the Brentskardhaugen Bed in western central Spitsbergen.
Assemblages tentatively referred to the $N$. pellucida CAZ were observed in the uppermost samples in DH2, and the identified species are consistent with a Late Bathonian-Callovian age. Comparable assemblages have been reported from the lower part of the Agardhfjellet Formation at Syltoppen and Sassenfjorden by Dypvik et al. (1985; Assemblage 3) and Bjærke (1980b; Zone $1)$, respectively. The age of the samples referred to the N. pellucida CAZ in DH2 is constrained upward by ammonites identified a few metres higher up by Koevoets et al. (2016). They reported finds of Kepplerites (Toricellites) aff. zortmanensis at $717.7 \mathrm{~m} \mathrm{MD}$ in DH2 and Kepplerites (Seymourites) svalbardensis at 663.8 $\mathrm{m} \mathrm{mD}$ in DH5R. These species were indicated to be of latest Bathonian-earliest Callovian age by Kopik \& Wierzbowski (1988). The uppermost sample (341.5 $\mathrm{m}$ ) in the Festningen range chart of Vigran et al. (2014) included several dinoflagellate cysts characteristic of Middle-Upper Jurassic assemblages including $N$. pellucida, Ctenidodinium ornatum, Chytroeisphaeridia chytroeides and Gonyaulacysta jurassica, but were nevertheless placed within the Wilhelmøya Subgroup. This sample was probably contaminated or misplaced.

\section{Sequence stratigraphy}

Based on the sedimentological and palynological framework established above, three sequences, sequences 1-3, have been defined within the Wilhelmøya Subgroup in western central Spitsbergen (Figs. 10 \& $11)$. Due to the thin and stratigraphically condensed development of the succession, however, recognition of parasequences, systematic shoreline trends and systems tracts of individual sequences is problematic and mostly beyond the resolution offered by the available data. The sequence boundaries separating individual sequences appear to have relatively limited erosional relief and are interpreted as polygenetic erosion surfaces formed by subaerial erosion during relative sea-level fall and subsequently modified during erosional transgression and submarine scour (i.e., ravinement; Demarest \& Kraft, 1987) during relative sea-level rise (e.g., Cattaneo \& Steel, 2003), thereby removing any unequivocal evidence of former subaerial exposure. The sequence boundaries are typically overlain by conglomeratic lag deposits (FA 1). Such deposits are considered common features of transgressive surfaces which coincide with subaerial unconformities (Van Wagoner et al., 1990; Kidwell, 1993).

\section{Sequence 1 (Early Norian)}

Sequence 1 (Figs. 3, $11 \& 12$ ) features deposits of the R. arctica CAZ and Heibergella CAZ in the study area, including the Slottet Bed at the base of the Wilhelmøya Subgroup. The sequence disconformably overlies the De Geerdalen Formation, and the basal sequence boundary is interpreted to coincide with a regional Early Norian 


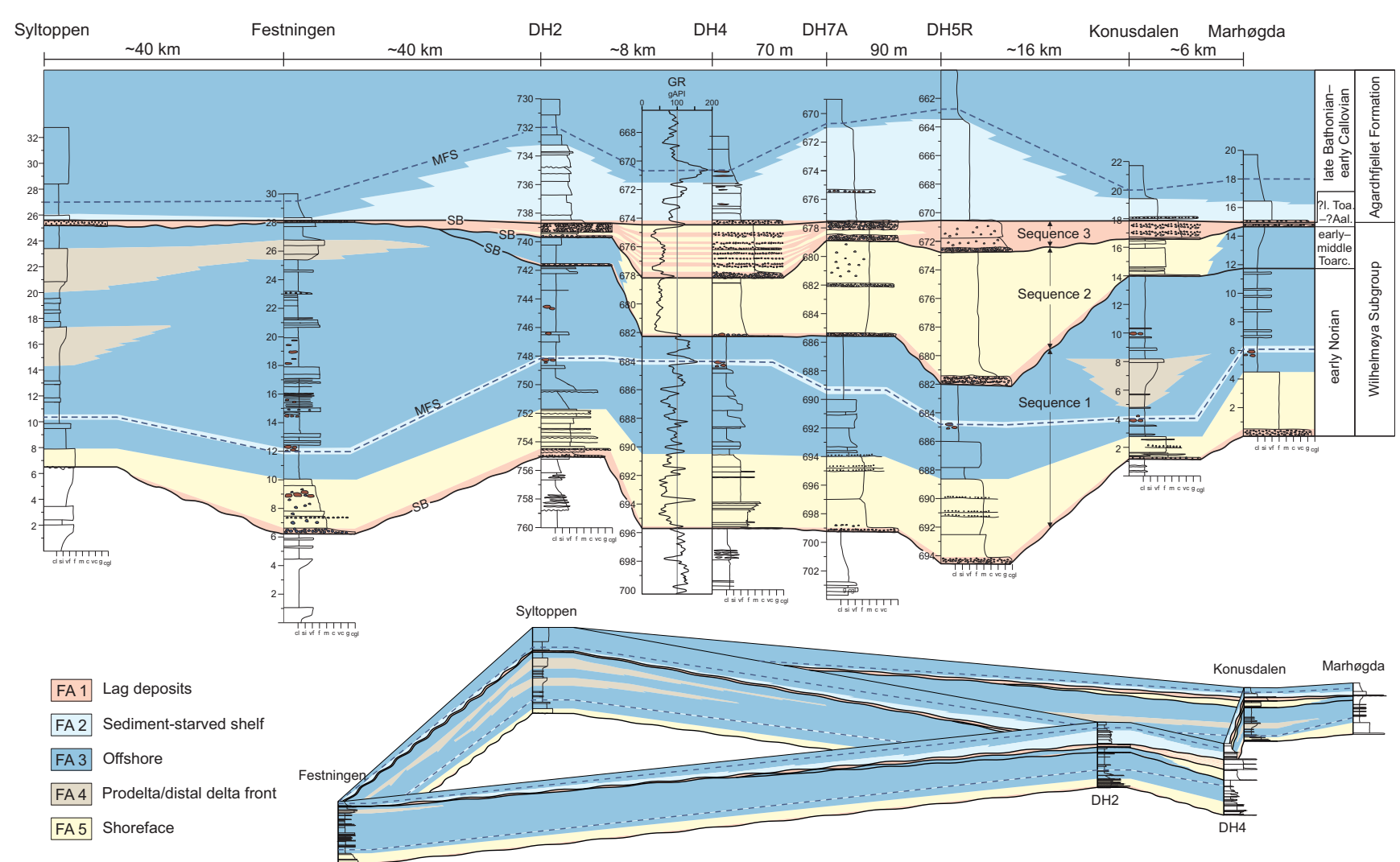

Figure 11. Correlation panel and fence diagram with sequence-stratigraphic interpretation and distribution of facies associations in the Wilhelmøya Subgroup in western central Spitsbergen. See Fig. 1 for location of log sections. The Syltoppen and Marhøgda sections are redrawn from Dypvik et al. (1985) and Bäckström \& Nagy (1985), respectively. Abbreviations: SB - sequence boundary, MFS - maximum flooding surface, GR gAPI - gamma-ray American Petroleum Industry.

disconformity and/or transgressive surface documented at the base of correlative successions in the southwestern Barents shelf and adjacent Arctic basins (Johannessen \& Embry, 1989; Mørk \& Smelror, 2001; Henriksen et al., 2011b). No associated hiatus has so far been documented at the base of this sequence by the available biostratigraphic data (Vigran et al., 2014; Paterson \& Mangerud, 2015), but the boundary is unconformable at least locally (Pčelina, 1980; Krajewski, 1992; Nagy \& Berge, 2008) and probably throughout Spitsbergen (e.g., Mørk et al., 1989). In Konusdalen, the irregular and erosional nature is evident when traced a short distance down-valley. The uppermost Isfjorden Member here includes $2 \mathrm{~m}$ of dark grey lagoonal mudstones overlain by a $2 \mathrm{~m}$-thick interval of red- and green-weathering mudstones with vertically elongated, irregularly shaped calcareous nodules, interpreted as rhizoliths (Fig. 12B). Approximately $50 \mathrm{~m}$ down-valley, the red- and greenweathering mudstones are absent and instead the Slottet Bed directly overlies the lagoonal mudstones below suggesting at least $2 \mathrm{~m}$ of erosion. Similar rhizolith horizons have also been observed in the uppermost De Geerdalen Formation in eastern Spitsbergen (Lord et al., 2017), suggesting periods of emergence and subaerial exposure prior to the Early Norian flooding event.
The lower part of Sequence 1 displays an upwardfining transgressive development (Figs. 11 \& 12; see also Bjærke \& Dypvik, 1977). A phosphatic conglomerate lag (FA 1) at the base of the Slottet Bed grades upward into shoreface sandstones (FA 5) and is subsequently overlain by offshore mudstones (FA 3) and glauconitic deposits (FA 2) suggesting upward-deepening and potentially a temporal decrease in sedimentation rates. The authigenic glauconite indicates development of a condensed section during maximum transgression (Loutit et al., 1988; Kidwell, 1989), and a maximum flooding surface (MFS) is placed at this level. In DH4, the position of this MFS is indicated by a distinct peak in the gamma ray (Fig. 12) whereas in Konusdalen the MFS is placed at a partly unconsolidated glauconitic bed (facies 2.3) approximately $1 \mathrm{~m}$ above the Slottet Bed (Fig. 12). The deposits overlying the MFS in sequence 1 are dominated by mudstones of FA 3. Correlative deposits in eastern Svalbard (Worsley, 1973; Mørk et al., 1999) and the southwestern Barents shelf (Henriksen et al., 2011b; Ryseth, 2014) form part of a much thicker and overall upward-coarsening regressive succession. A comparable but considerably thinner development is also likely to have occurred within the present study area but may have been removed by subsequent erosion. A notable exception is the presence of 

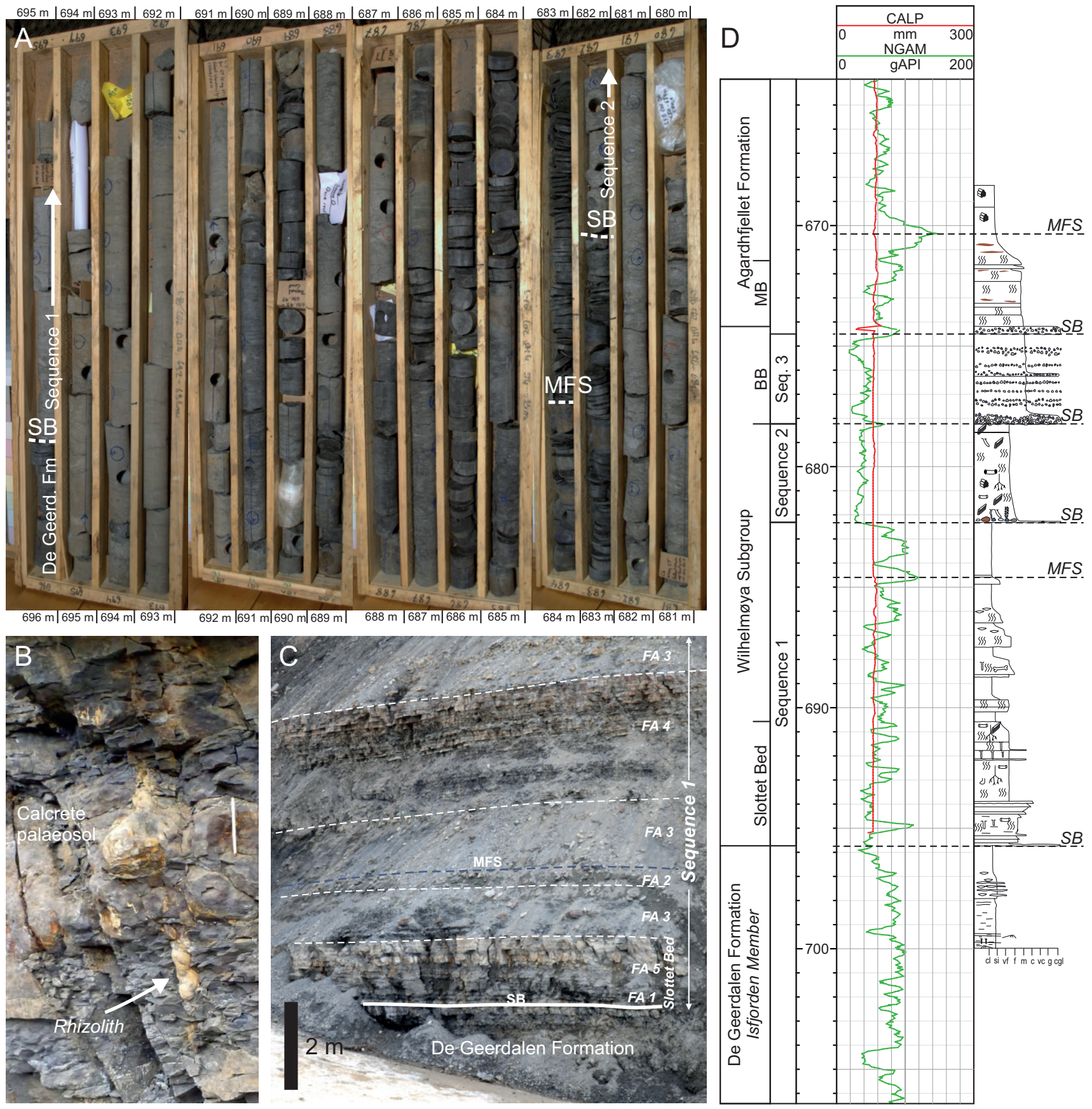

Figure 12. Sequences and sequence-stratigraphic surfaces in the Wilhelmøya Subgroup in DH4 (A, D) and Konusdalen (B, C). (A) Core section through the uppermost De Geerdalen Formation, Sequence 1 and the lower part of Sequence 2 in DH4. Way up from lower left to upper right. (B) Well-defined rhizolith in a calcrete palaeosol horizon within the uppermost De Geerdalen Formation in Konusdalen. (C) Outcrop section through the lower part of Sequence 1 in Konusdalen. (D) Sequences and sequence-stratigraphic surfaces in DH4. Abbreviations: NGAM - natural gamma ray, gAPI - gamma-ray American Petroleum Industry, CALP - caliper, SB - sequence boundary, MFS - maximum flooding surface.

thin upward-coarsening units (FA 4) in Konusdalen and 'Criocerasdalen'. These are interpreted to correlate with subtle upward-coarsening units identified at Syltoppen by Dypvik et al. (1985). Accordingly, Sequence 1 is interpreted to form a top-truncated transgressive-regressive (T-R) sequence with no or only limited preservation of its regressive portion.

\section{Sequence 2 (Early-Middle Toarcian)}

Sequence 2 (Figs. 3, 11 \& 12) encompasses deposits referred to the N. senex CAZ of probable Early-Middle Toarcian age. Maximum thicknesses are observed in the Adventdalen wells (4-9 m), and the sequence subsequently thins towards the north and west and is absent at both Syltoppen and Festningen. The sequence features sandstones of FA 5 in Adventdalen and Konusdalen which 
grade laterally into mudstones of FA 3 in $\mathrm{DH} 2$ and at Marhøgda. According to the palynological data, the base records a lacuna spanning the ?Middle Norian-earliest Toarcian (Fig. 3), probably reflecting extended periods of subaerial exposure, erosion and/or non-deposition. The lithological expression of this unconformity changes laterally within the study area but is commonly marked by a thin polymictic conglomerate (FA 1). At Marhøgda, the sequence boundary is inconspicuous visually and only recorded by a distinct change in palynomorph assemblages between under- and overlying mudstones of FA 3 (Bjærke \& Dypvik, 1977). Observations of increasing plant debris, and a subtle upward-coarsening trend at Marhøgda led Bjærke \& Dypvik (1977) to propose a regressive development for sequence 2 (their Unit E) at Marhøgda. Correlative strata of the Svenskøya Formation (Wilhelmøya Subgroup) on the eastern coast of Spitsbergen, however, form an overall transgressive LowerMiddle Toarcian sequence, interrupted by regressive pulses and higher-frequency breaks in sedimentation (Rismyhr et al., unpublished data). This indicates that the development and preservation of different components of individual sequences (e.g., transgressive or regressive) may have varied markedly across Spitsbergen, probably as a result of lateral variations in subsidence rates (i.e., accommodation space).

\section{Sequence 3 (Late Toarcian-Aalenian)}

Sequence 3 (Figs. $3 \& 11$ ) includes deposits of the 0.2 to 4 m-thick Brentskardhaugen Bed, which is observed at the top of the Wilhelmøya Subgroup in all studied drillcores and outcrop sections. The lower and upper boundaries represent important unconformities which are recognised throughout Svalbard (Pčelina, 1980; Wierzbowski et al., 1981; Bäckström \& Nagy, 1985; Mørk et al., 1999; Nagy \& Berge, 2008), but the timing is relatively poorly constrained by the available biostratigraphic data. Ammonites and bivalves observed within phosphate nodules of the Brentskardhaugen Bed indicate a Middle or Late Toarcian-Aalenian age, possibly extending into the Bajocian (Birkenmajer \& Pugaczewska, 1975; Pčelina, 1980; Wierzbowski et al., 1981; Bäckström \& Nagy, 1985), but may subsequently have been reworked and redeposited at a later stage. Well-preserved palynomorphs observed within the same phosphate nodules also point toward a Late Toarcian-Aalenian age (i.e., P. eumekes CAZ; Bjærke, 1980a; Below, 1987a, b; Smelror \& Below, 1992), whereas shales at the base of the Agardhfjellet Formation have been dated as Late Bathonian-Callovian based on ammonites (Kopik \& Wierzbowski, 1988; Koevoets et al., 2016), foraminifera (Nagy \& Basov, 1998) and palynomorph assemblages (Bjærke, 1980b).

Interpretations of the Brentskardhaugen Bed have differed widely both in terms of its depositional age, development and stratigraphic affiliation (Mørk et al., 1999, and references therein). Several authors have regarded the Brentskardhaugen Bed as a transgressive lag deposited at the start of a late Middle Jurassic transgression and consequently placed it at the base of the Agardhfjellet Formation (e.g., Birkenmajer, 1972; Birkenmajer \& Pugaczewska, 1975; Bäckström \& Nagy, 1985; Dypvik et al., 1985, 1991; Nagy \& Berge, 2008; Nagy et al., 2011). In contrast, others have considered the Brentskardhaugen Bed to be an integral part of the Wilhelmøya Subgroup (e.g., Worsley, 1973; Pčelina, 1980; Mørk et al., 1982; Maher, 1989; Krajewski, 1990, 1992; Mørk et al., 1999; this study) although with various interpretations with regard to depositional mechanisms. Maher (1989) suggested the Brentskardhaugen Bed formed as a mega-storm deposit following a single or a series of short-lived storm events on a shallow shelf. This interpretation was based on various observations which he argued were more consistent with storm deposition rather than a transgressive lag origin, including its poor sorting, local grading (normal and reverse), and an apparent lack of lateral and internal discontinuities. A firm distinction between storm and transgressive lag deposits, however, seems somewhat artificial considering that storm and wave processes which act during erosional shoreline retreat and the development of a transgressive ravinement surface will also likely influence contemporaneous deposition of transgressive lags farther seaward (Demarest \& Kraft, 1987; Nummedal \& Swift, 1987; Cattaneo \& Steel, 2003). Sedimentary features indicating wave and storm influence could therefore be expected within transgressive lag deposits (e.g., Hwang \& Heller, 2002).

Phosphorite conglomerates comparable to those observed within the Brentskardhaugen Bed have been widely documented in the southwestern Barents shelf within and at the top of the Pliensbachian-Bajocian Stø Formation (Gjelberg et al., 1987; Bugge et al., 2002; Klausen et al., 2018) where they commonly occur on transgressive ravinement surfaces separating shallowingupward shoreline successions (Gjelberg et al., 1987). In eastern and southern Spitsbergen phosphate nodules and phosphorite conglomerates have also been reported from Toarcian-Aalenian shallow and marginal marine sandstone beds below the Brentskardhaugen Bed (sensu stricto) in the upper part of the Wilhelmøya Subgroup (Worsley, 1973; Smith, 1975; Bjærke, 1980a; Bäckström \& Nagy, 1985; Krajewski, 1992). These sandstones were suggested by Pčelina (1980) and Krajewski (1990, 1992) to represent less stratigraphically condensed lateral equivalents of the Brentskardhaugen Bed in central Spitsbergen, and the phosphate nodules apparently yield ammonite faunas similar to those of the Brentskardhaugen Bed (Bjærke, 1980a; Pčelina, 1980). Pčelina (1980) distinguished 3-7 phosphoritic horizons within the Brentskardhaugen Bed and correlative strata and argued that each represented deposits of discrete depositional episodes during the ToarcianBathonian. In southern Spitsbergen, Krajewski (1992) identified at least four such phosphorite horizons 


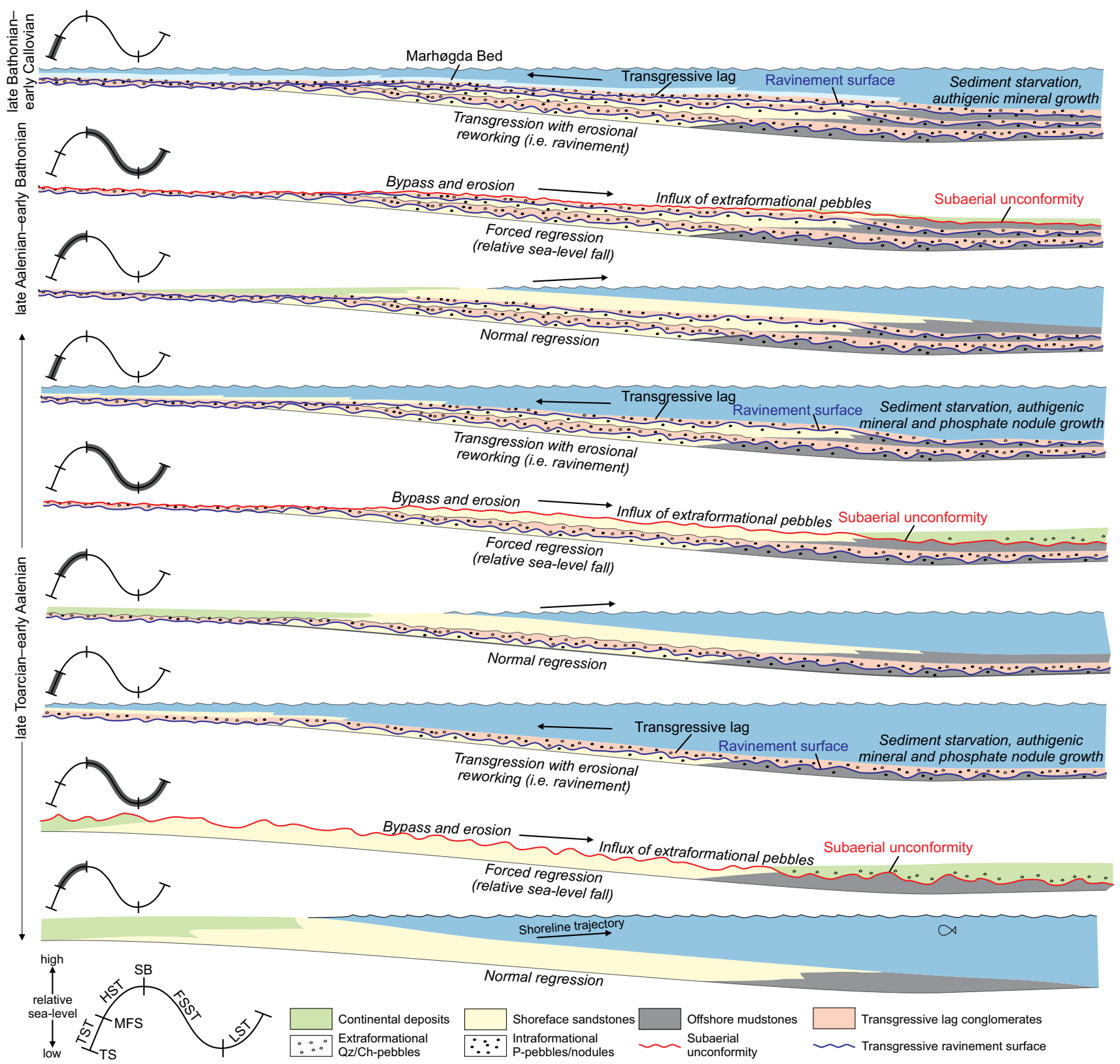

Figure 13. Schematic model for the development of condensed high-frequency sequences as suggested for the Brentskardhaugen Bed (sequence 3). A very gentle depositional gradient coupled with low subsidence rates facilitated rapid lateral shoreline shifts and extensive reworking and redistribution of sediments. The resulting deposits consist of thin shoreface sandstones interbedded with transgressive lags. Any fluvial and coastal plain deposits which may have accumulated during relative sea-level lowstands were removed during erosional transgressions, leaving no unequivocal evidence of subaerial exposure. The sequence boundaries are formed by polygenetic surfaces consisting of combined subaerial unconformities and transgressive ravinement surfaces. Abbreviations: TST - transgressive systems tract, TS - transgressive surface, HST - Highstand systems tract, MFS - maximum flooding surface, SB - sequence boundary, FSST - falling stage systems tract, LST - lowstand systems tract.

within Toarcian-Aalenian sandstones. In the present study area, a comparable development is observed in DH4 where several phosphorite conglomerate horizons occur interbedded with sandstones of FA 5 within the Brentskardhaugen Bed (Fig. 11).

Krajewski (1992) presented a model for the development of the Brenskardhaugen Bed and correlative deposits in southern Spitsbergen which involved repeated regressive phases with deposition of marginal and shallow-marine sediments punctuated by rapid transgressive episodes characterised by sediment starvation, phosphate nodule growth, and sediment winnowing and reworking. A similar model was presented by Gjelberg et al. (1987) to explain the mechanisms for the development of widespread sheet-sands in the Stø Formation in the southwestern Barents shelf. The model of Krajewski (1992) is generally supported in this study, though with some minor modifications. Krajewski (1992) proposed that the thin Brentskardhaugen Bed in central Spitsbergen 
compared to correlative deposits in southern Spitsbergen was the result of minimal sediment input and remoteness from a coeval southwestern shoreline. We conversely propose that western central Spitsbergen was located in a more proximal position to the coeval shoreline than southern Spitsbergen, and that limited accommodation space and not sediment input was the main factor limiting the thickness of the preserved deposits. Using this model, the increased stratigraphic condensation of the Brentskardhaugen Bed and correlative deposits in western central Spitsbergen can be explained by a higher degree of sequence amalgamation, erosion and/ or reworking than in areas farther to the south and east on Spitsbergen. Accordingly, sequence 3 (and the Brentskardhaugen Bed) is interpreted to record repeated deposition, partial erosion, reworking and condensation of a series of high-frequency Upper Toarcian-Aalenian sequences (Fig. 13). Locally, the Brentskardhaugen Bed, or parts of it, may subsequently have been reworked and redeposited as a basal transgressive lag during a regional Bathonian transgression. In a sequencestratigraphic sense the Brentskardhaugen Bed may therefore encompass deposits from at least two different low-frequency sequences, including sequence 3 (Late Toarcian-Aalenian) and the overlying Bathonian-Lower Oxfordian T-R sequence defined at the base of the Agardhfjellet Formation (TR1; Koevoets et al., 2019). This T-R sequence includes deposits of FA 2 referred to the Marhøgda Bed, and the base records an abrupt shut-off of coarse-grained clastic sediment supply. These deposits grade upward into dark grey organic-rich shales (FA 3) of the Agardhfjellet Formation, with an MFS indicated by a distinct peak in the gamma-ray curve at $671 \mathrm{~m} \mathrm{MD}$ in DH4 (Figs. 11 \& 12).

\section{Palaeogeographic development and controls}

The sedimentological and sequence-stratigraphic analyses above have established that the Wilhelmøya Subgroup in western central Spitsbergen comprises waveinfluenced marginal marine and shallow shelf sediments deposited during three distinct depositional episodes (sequences 1-3) interrupted by extended periods of erosion, sediment bypass and/or non-deposition. Following the Early Norian flooding event, recorded as a transgressive succession starting with the Slottet Bed at the base of sequence 1, open marine shelf environments prevailed throughout the study area. The presence of small-scale upward-coarsening units containing prodelta and distal delta-front deposits suggests that point sources may have facilitated local progradation of relatively small deltaic tongues into central western Spitsbergen during the Early Norian.

A relative sea-level fall in the Late Norian-Rhaetian, probably amplified by uplift of Spitsbergen in the Late Triassic-Early Jurassic (e.g., Nøttvedt et al., 1993b; Grogan et al., 1999), led the study area to become subaerially exposed and subject to erosion and sediment bypass. Sedimentation probably did not recommence until accommodation space, albeit limited, again became available following a regional relative sea-level rise which culminated in the Early-Middle Toarcian. Limited accommodation space coupled with repeated fluctuations in relative sea level in the Late Toarcian-Aalenian led to the development of a thin and condensed succession comprising compositionally mature shoreface sandstones locally interbedded with transgressive lag conglomerates (Fig. 13). Following a relative sea-level fall in the late Aalenian-Bajocian (Fig. 13; e.g., Pčelina, 1980; Bäckström \& Nagy, 1985; Smelror et al., 2009), the study area again became subaerially exposed leaving no depositional records from the Late Aalenian-Early Bathonian. A regional Bathonian transgression terminated deposition of the Wilhelmøya Subgroup and established offshore shelf environments throughout the region.

The thin Wilhelmøya Subgroup in the study area and its closely spaced unconformities are consistent with very limited accommodation space (i.e., subsidence rates) and low sedimentation rates during the latest TriassicMiddle Jurassic interval in Spitsbergen (e.g., Johannessen \& Embry, 1989). The epicontinental setting inferred for the Barents shelf during the Late Triassic-Middle Jurassic (e.g., Petrov et al., 2008; Anell et al., 2014) also points toward a basin physiography characterised by very gentle depositional gradients (e.g., Johnson \& Baldwin, 1996; Suter, 2006). This is supported by the relatively small variations in total thickness of the Wilhelmøya Subgroup throughout the study area as well as the limited erosional relief associated with the unconformities, both suggesting the amount of fluvial incision during relative sea-level lowstands was minimal. This is a typical feature of low-gradient ramp-type shelves which lack a distinct shelf edge (Posamentier \& Allen, 1999). Lowgradient shelves are also highly sensitive to relative sea-level fluctuations, and even small variations may cause rapid and significant relocations of the shoreline (Posamentier \& Allen, 1999). A rise in relative sea level in this type of physiographic setting would lead to rapid landward migration of the shoreline, causing sediments to be trapped within the coastal zone. More distal parts of the shelf would consequently become starved of clastic sediment and thereby sites prone to precipitation of authigenic minerals (i.e., glauconite and phosphate). A fall in relative sea level, on the other hand, would allow river systems to rapidly extend far out onto the subaerially exposed shelf forming a widespread zone of sediment bypass and erosion.

The extraformational pebbles (i.e., quartz, quartzite and chert) which are observed in conglomerates at several levels in the Wilhelmøya Subgroup may originally have been brought into the study area through such river systems. The pebbles were probably deposited as fluvial conglomerates which were subsequently subjected to transgressive erosion and reworking, mixed with phosphate nodules and ultimately redeposited as coarse- 
grained transgressive lags during ensuing relative rises in sea level. Potential sources for the extraformational pebbles were probably located to the west and/or north of the study area. In the Wandel Sea Basin in northeastern Greenland, a Middle Triassic-Late Jurassic hiatus is documented (e.g., Håkansson \& Stemmerik, 1989) suggesting that this area was exposed and eroded contemporaneously with deposition of the Wilhelmøya Subgroup in Svalbard. This is corroborated by zircon age signatures documented within the Wilhelmøya Subgroup (Bue \& Andresen, 2013) which indicate renewed sediment influx from the west in the latest Triassic-Middle Jurassic. An alternative, or additional potential source area may have been located in northern Spitsbergen or areas immediately north of Svalbard. Based on apatite fission track analysis from northern Spitsbergen, Dörr et al. (2012) concluded that these areas were exhumed and eroded in the Early Jurassic and interpreted this as a response to rift-shoulder uplift associated with the opening of the proto-Amerasia Basin. Buiter \& Torsvik (2007) also indicated uplift of areas north of Svalbard during the latest Triassic-Early Jurassic, but in response to compressional forces caused by a collision between the Lomonosov Ridge and the northern Barents shelf margin.

Additional tectonic movements in the region which may have influenced the development of the Wilhelmøya Subgroup in Svalbard include the westward protrusion of the Novaya Zemlya fold-and-thrust belt in the Late Triassic to Early Jurassic (Buiter \& Torsvik, 2007; Petrov et al., 2008). These particular movements may have contributed to the western parts of the Barents shelf becoming areas characterised by low accommodation due to regional forebulge development (Klausen et al., 2017).

\section{Conclusions}

Through an integrated characterisation of the Wilhelmøya Subgroup in drillcores and outcrops in western central Spitsbergen we conclude that:

- The succession reflects deposition in marginal and shallow-marine, periodically sediment-starved, offshore shelf environments.

- Palynological analysis suggests that the Wilhelmøya Subgroup in central western Spitsbergen can be subdivided into three unconformity-bounded sequences. Sequence 1 (early Norian) and sequence 3 (?late Toarcian-Aalenian) are present throughout the study area, whereas sequence 2 (early-middle Toarcian) thins gradually and becomes absent towards the west and north. The sequence boundaries are interpreted to represent polygenetic erosion surfaces reflecting extended periods of subaerial erosion followed by erosional transgression (i.e., ravinement).

- A physiographic setting characterised by gentle depositional gradients (i.e., epicontinental ramptype shelf) facilitated rapid shoreline movements in response to relatively modest variations in relative sea level during deposition of the Wilhelmøya Subgroup. This, coupled with very low subsidence rates especially during the Early-Middle Jurassic, caused partial erosion, reworking and condensation of a series of high-frequency sequences, exemplified by the interbedding of polymictic phosphorite conglomerates and shoreface deposits in the Brentskardhaugen Bed.

- The extraformational pebbles observed within the Brentskardhaugen Bed and other conglomerates of the Wilhelmøya Subgroup are suggested to have been supplied from uplifted and exposed margins to the west and/or north of the study area.

Acknowledgements. This study is part of the research project Fasena funded by Eni Norge AS. Eni Norge AS is also gratefully acknowledged for covering additional expenses associated with the preparation of palynological samples used in this study. The study utilises data collected in association with the UNIS $\mathrm{CO}_{2}$ Lab project (http://co2cCs.unis.no) supported by FME-SUCCESS and industry partners ConocoPhillips, Statoil, Store Norske Spitsbergen Kulkompani, Statkraft, Lundin Norway, Baker Hughes, and Leonhard Nilsen \& Sønner. Reviewer Morten Smelror and editor Trond Slagstad are kindly thanked for their comments and suggestions which have greatly improved the quality and clarity of the manuscript. This is a contribution of the NCCS (RCN\# 257579).

\section{References}

Amorosi, A. 2012: The occurrence of glaucony in the stratigraphic record: distribution patterns and sequence冈stratigraphic significance. In Morad, S., Ketzer, M. \& de Ros, L.F. (eds.): Linking Diagenesis to Sequence Stratigraphy, Special Publication 45 of the International Association of Sedimentologists, pp. 37-53. https://doi.org/10.1002/9781118485347.ch2.

Anell, I., Braathen, A. \& Olaussen, S. 2014: The Triassic-Early Jurassic of the northern Barents Shelf: a regional understanding of the Longyearbyen $\mathrm{CO}_{2}$ reservoir. Norwegian Journal of Geology 94, 83-98.

Ask, M. 2013: Palynological dating of the upper part of the De Geerdalen Formation on central parts of Spitsbergen and Hopen. MSc Thesis, University of Bergen, 79 pp.

Bäckström, S.A. \& Nagy, J. 1985: Depositional history and fauna of a Jurassic phosphorite conglomerate (the Brentskardhaugen Bed) in Spitsbergen. Norsk Polarinstitutt Skrifter 183, 1-61.

Below, R. 1987a: Evolution und Systematick von DinoflagellatenZysten aus der Ordnund Peridiniales I. Allgemeine Grundlagen und Subfamilie Rhaetogonyaulacoideae (Familie Peridiniaceae). Palaeontographica, Abteilung B 205, 1-164.

Below, R. 1987b: Evolution und Systematik von DinoflagellatenZysten aus der Ordnung Peridiniales II. Cladopyxiaeae unde Valvaeodiniaceae. Palaeontolographica, Abteilung B 205, 1-115.

Bergan, M. \& Knarud, R. 1993: Apparent changes in clastic mineralogy of the Triassic-Jurassic succession, Norwegian Barents Sea: 
possible implications for palaeodrainage and subsidence. In Vorren, T.O., Bergsager, E., Dahl-Stamnes, Ø.A., Holter, E., Johansen, B., Lie, E. \& Lund, T.B. (eds.): Arctic Geology and Petroleum Potential, Norwegian Petroleum Society Special Publication 2, pp. 481-493. https://doi.org/10.1016/B978-0-444-88943-0.50034-4.

Bergh, S.G., Braathen, A. \& Andresen, A. 1997: Interaction of basement-involved and thin-skinned tectonism in the Tertiary fold-thrust belt of central Spitsbergen, Svalbard. American Association of Petroleum Geologists Bulletin 81, 637-661.

https://doi.org/10.1306/522B43F7-1727-11D7-8645000102C1865D.

Birkenmajer, K. 1972: Megaripples and phosphorite pebbles in the Rhaeto-Liassic beds south of Van Keulenfjorden, Spitsbergen. Norsk Polarinstitutt Årbok 1970, 117-127.

Birkenmajer, K. \& Pugaczewska, H. 1975: Jurassic and Lower Cretaceous marine fauna of SW Torell Land, Spitsbergen. Studia Geologica Polonica 44, 45-89.

Bjærke, T. 1977: Mesozoic palynology of Svalbard II. Palynomorphs from the Mesozoic sequence of Kong Karls Land. Norsk Polarinstitutt Årbok 1976, 83-120.

Bjærke, T. 1980a: Mesozoic palynology of Svalbard IV. Toarcian dinoflagellates from Spitsbergen. Palynology 4, 57-77. https://doi.org/10.1080/01916122.1980.9989202.

Bjærke, T. 1980b: Mesozoic palynology of Svalbard V. Dinoflagellates from the Agardhfjellet Member (Middle and Upper Jurassic) in Spitsbergen. Norsk Polarinstitutt Skrifter 172, 145-167.

Bjærke, T. \& Dypvik, H. 1977: Sedimentological and palynological studies of Upper Triassic-Lower Jurassic sediments in Sassenfjorden, Spitsbergen. Norsk Polarinstitutt Årbok 1976, 131150.

Bjærke, T. \& Manum, S. 1977: Mesozoic Palynology of Svalbard: The Rhaetian of Hopen, with a Preliminary Report of the Rhaetian and Jurassic of Kong Karls Land. Norsk Polarinstitutt Skrifter 165, 1-48.

Bonis, N., Kürschner, W. \& Krystyn, L. 2009: A detailed palynological study of the Triassic-Jurassic transition in key sections of the Eiberg Basin (Northern Calcareous Alps, Austria). Review of Palaeobotany and Palynology 156, 376-400. https://doi.org/10.1016/j.revpalbo.2009.04.003.

Braathen, A., Baelum, K., Christiansen, H., Dahl, T., Eiken, O., Elvebakk, H., Hansen, F., Hanssen, T., Jochmann, M., Johansen, T.A., Johnsen, H., Larsen, L., Lie, T., Mertes, J., Mørk, A., Mørk, M.B., Nemec, W., Olaussen, S., Oye, V., Rød, K., Titlestad, G.O., Tveranger, J. \& Vagle, K. 2012: The Longyearbyen $\mathrm{CO}_{2}$ Lab of Svalbard, Norway-initial assessment of the geological conditions for $\mathrm{CO}_{2}$ sequestration. Norwegian Journal of Geology 92, 353-376.

Bromley, R.G. \& Mørk, A. 2000: The trace fossil Phoebichnus trochoides in the condensed Triassic-Jurassic-boundary strata of Svalbard. Zentralblatt für Geologie und Paläontologie Teil I 1998, 1431-1439.

Bue, E.P. \& Andresen, A. 2013: Constraining depositional models in the Barents Sea region using detrital zircon $\mathrm{U}-\mathrm{Pb}$ data from Mesozoic sediments in Svalbard. In Scott, R.A., Smyth, H.R., Morton, A.C. \& Richardson, N. (eds.): Sediment Provenance Studies in Hydrocarbon Exploration and Production, Geological Society of London Special Publication 386, pp. 261-279. https://doi.org/10.1144/SP386.14.

Bugge, T., Elvebakk, G., Fanavoll, S., Mangerud, G., Smelror, M., Weiss, H.M., Gjelberg, J., Kristensen, S.E. \& Nilsen, K. 2002: Shallow stratigraphic drilling applied in hydrocarbon exploration of the Nordkapp Basin, Barents Sea. Marine and Petroleum Geology 19, 13-37. https://doi.org/10.1016/S0264-8172(01)00051-4.

Buiter, S.J. \& Torsvik, T.H. 2007: Horizontal movements in the eastern Barents Sea constrained by numerical models and plate reconstructions. Geophysical Journal International 171, 1376-1389. https://doi.org/10.1111/j.1365-246X.2007.03595.x.

Bujak, J.P. \& Fisher, M.J. 1976: Dinoflagellate cysts from the Upper Triassic of Arctic Canada. Micropaleontology 22, 44-70. https://doi.org/10.2307/1485320.
Bælum, K., Johansen, T.A., Johnsen, H., Rød, K., Ruud, B.O. \& Braathen, A. 2012: Subsurface structures of the Longyearbyen $\mathrm{CO}_{2} \mathrm{Lab}$ study are in Central Spitsbergen (Arctic Norway), as mapped by reflection seismic data. Norwegian Journal of Geology 92, 377-389.

Cattaneo, A. \& Steel, R.J. 2003: Transgressive deposits: a review of their variability. Earth-Science Reviews 62, 187-228. https://doi.org/10.1016/S0012-8252(02)00134-4.

Clifton, H.E. 2006: A reexamination of facies models for clastic shorelines. In Posamentier, H.W. \& Walker, R.G. (eds.): Facies Models Revisited, Society for Sedimentary Geology Special Publication 84,pp. 293-338. https://doi.org/10.2110/pec.06.84.0293.

Clifton, H.E., Hunter, R.E. \& Phillips, R.L. 1971: Depositional structures and processes in the non-barred high-energy nearshore. Journal of Sedimentary Research 41, 651-670. https://doi.org/10.1306/74D7231A-2B21-11D7-8648000102C1865D. Dallmann, W.K. (ed.) 2015: Geoscience Atlas of Svalbard. Report series no. 148, Norwegian Polar Institute, Tromsø, 292 pp.

Demarest, J.M. \& Kraft, J.C. 1987: Stratigraphic record of Quaternary sea levels: implications for more ancient strata. In Nummedal, D., Pilkey, O.H. \& Howard, J.D. (eds.): Sea-level fluctuations and coastal evolution, Society for Sedimentary Geology Special Publication 41, pp. 223-239. https://doi.org/10.2110/pec.87.41.0223.

Dimakis, P., Braathen, B.I., Faleide, J.I., Elverhøi, A. \& Gudlaugsson, S.T. 1998: Cenozoic erosion and the preglacial uplift of the SvalbardBarents Sea region. Tectonophysics 300, 311-327. https://doi.org/10.1016/S0040-1951(98)00245-5.

Dörr, N., Lisker, F., Clift, P., Carter, A., Gee, D.G., Tebenkov, A. \& Spiegel, C. 2012: Late Mesozoic-Cenozoic exhumation history of northern Svalbard and its regional significance: Constraints from apatite fission track analysis. Tectonophysics 514, 81-92. https://doi.org/10.1016/j.tecto.2011.10.007.

Dott, R.H. \& Bourgeois, J. 1982: Hummocky stratification: significance of its variable bedding sequences. Geological Society of America Bulletin 93, 663-680. https://doi.org/10.1130/0016-7606(1982)93<663:HSSOIV>2.0.CO;2.

Dumas, S. \& Arnott, R. 2006: Origin of hummocky and swaley crossstratification-the controlling influence of unidirectional current strength and aggradation rate. Geology 34, 1073-1076. https://doi.org/10.1130/G22930A.1.

Dypvik, H., Hvoslef, S., Bjærke, T. \& Finnerud, E. 1985: The Wilhelmøya Formation (Upper Triassic - Lower Jurassic) at Bohemanflya, Spitsbergen. Polar Research 3, 155-165. https://doi.org/10.3402/polar.v3i2.6949.

Dypvik, H., Nagy, J., Eikeland, T., Backer-Owe, K. \& Johansen, H. 1991: Depositional conditions of the Bathonian to Hauterivian Janusfjellet Subgroup, Spitsbergen. Sedimentary Geology 72, 55-78. https://doi.org/10.1016/0037-0738(91)90123-U.

Elvebakk, H. 2010: Results of borehole logging in well LYB CO2 Dh4 of 2009, Longyearbyen, Svalbard. Norges geologiske undersøkelse Report 2010.018, 35 pp.

Faleide, J., Vågnes, E. \& Gudlaugsson, S. 1993: Late Mesozoic-Cenozoic evolution of the southwestern Barents Sea. In Parker, J.R. (ed.): Petroleum Geology of Northwest Europe: Proceedings of the $4^{\text {th }}$ Conference, Geological Society of London Petroleum Geology Conference Series 4, pp. 933-950. https://doi.org/10.1144/0040933.

Faleide, J.I., Bjørlykke, K. \& Gabrielsen, R.H. 2015: Chapter 22 Geology of the Norwegian continental shelf. In Bjørlykke, K. (ed.): Petroleum Geoscience: From Sedimentary Environments to Rock Physics, Second Edition, Springer, Berlin Heidelberg, pp. 603-637. https://doi.org/10.1007/978-3-642-34132-8_25.

Farokhpoor, R., Torsæter, O., Baghbanbashi, T., Mørk, A. \& Lindeberg, E.G. 2010: Experimental and numerical simulation of $\mathrm{CO}_{2}$ injection into Upper Triassic sandstones in Svalbard, Norway. Abstracts and Proceedings, Society of Petroleum Engineers International Conference on $\mathrm{CO}_{2}$ Capture, Storage and Utilization, 10-12 November, New Orleans, Louisiana, USA, SPE 139524. https://doi.org/10.2118/139524-MS. 
Fiksdal, B. 1988: Palynologiske undersøkelser av Wilhelmøyaformasjonens øvre del på Kong Karls Land, Svalbard. Thesis in botany, Pre-Quartenary biostratigraphy, University in Trondheim, $96 \mathrm{pp}$.

Fleming, E.J., Flowerdew, M.J., Smyth, H.R., Scott, R.A., Morton, A.C., Omma, J.E., Frei, D. \& Whitehouse, M.J. 2016: Provenance of Triassic sandstones on the southwest Barents Shelf and the implication for sediment dispersal patterns in northwest Pangaea. Marine and Petroleum Geology 78, 516-535.

https://doi.org/10.1016/j.marpetgeo.2016.10.005.

Föllmi, K. 1996: The phosphorus cycle, phosphogenesis and marine phosphate-rich deposits. Earth-Science Reviews 40, 55-124. https://doi.org/10.1016/0012-8252(95)00049-6.

Gjelberg, J., Dreyer, T., Høie, A., Tjelland, T. \& Lilleng, T. 1987: Late Triassic to Mid-Jurassic sandbody development on the Barents and Mid-Norwegian shelf. In Brooks, J. \& Glennie, K. (eds.): Petroleum Geology of Northwest Europe: Proceedings of the $3^{\text {rd }}$ Conference, Geological Society of London Petroleum Geology Conference Series 3, pp. 1105-1129.

Glenn, C.R., Follmi, K.B., Riggs, S.R., Baturin, G.N., Grimm, K.A., Trappe, J., Abed, A.M., Galli-Olivier, C., Garrison, R.E. \& Ilyin, A. 1994: Phosphorus and phosphorites: sedimentology and environments of formation. Eclogae Geologicae Helvetiae 87, 747-788.

Glørstad-Clark, E., Faleide, J.I., Lundschien, B.A. \& Nystuen, J.P. 2010: Triassic seismic sequence stratigraphy and paleogeography of the western Barents Sea area. Marine and Petroleum Geology 27, 14481475. https://doi.org/10.1016/j.marpetgeo.2010.02.008.

Grogan, P., Østvedt-Ghazi, A.M., Larssen, G., Fotland, B., Nyberg, K., Dahlgren, S. \& Eidvin, T. 1999: Structural elements and petroleum geology of the Norwegian sector of the northern Barents Sea. In Fleet, A. \& Boldy, S. (eds.): Petroleum Geology of Northwest Europe: Proceedings of the 5th Conference, Geological Society of London Petroleum Geology Conference Series 5, pp. 247-259. https://doi.org/10.1144/0050247.

Grundvåg, S.-A., Marin, D., Kairanov, B., Śliwińska, K., Nøhr-Hansen, H., Escalona, A. \& Olaussen, S. 2017: The Lower Cretaceous succession of the northwestern Barents Shelf: Onshore and offshore correlations. Marine and Petroleum Geology 86, 834-857. https://doi.org/10.1016/j.marpetgeo.2017.06.036.

Haugen, T. 2016: A Sedimentological Study of the De Geerdalen Formation with Focus on the Isfjorden Member and Palaeosols. MSc thesis, NTNU, 129 pp.

Heinberg, C. \& Birkelund, T. 1984: Trace-fossil assemblages and basin evolution of the Vardekløft Formation (Middle Jurassic, central East Greenland). Journal of Paleontology 58, 362-397.

Hendriks, B.W. \& Andriessen, P.A. 2002: Pattern and timing of the post-Caledonian denudation of northern Scandinavia constrained by apatite fission-track thermochronology. In Doré, A.G., Cartwright, J.A., Stoker, M.S., Turner, J.P. \& White, N. (eds.): Exhumation of the North Atlantic Margin: Timing, Mechanisms and Implications for Petroleum Exploration, Geological Society of London Special Publication 196, pp. 117-137. https://doi.org/10.1144/GSL.SP.2002.196.01.08.

Henriksen, E., Bjørnseth, H.M., Hals, T.K., Heide, T., Kiryukhina, T., Kløvjan, O.S., Larssen, G.B., Ryseth, A.E., Rønning, K. \& Sollid, K. 2011a: Uplift and erosion of the greater Barents Sea: impact on prospectivity and petroleum systems. In Spencer, A.M., Embry, A.F., Gautier, D.L., Stoupakova, A.V. \& Sørensen, K. (eds.): Arctic Petroleum Geology, Geological Society of London Memoirs 35, pp. 271-281. https://doi.org/10.1144/M35.17.

Henriksen, E., Ryseth, A.E., Larssen, G.B., Heide, T., Rønning, K., Sollid, K. \& Stoupakova, A.V. 2011b: Tectonostratigraphy of the greater Barents Sea: implications for petroleum systems. In Spencer, A.M., Embry, A.F., Gautier, D.L., Stoupakova, A.V. \& Sørensen, K. (eds.): Arctic Petroleum Geology, Geological Society of London Memoirs 35, pp. 163-195. https://doi.org/10.1144/M35.10.
Hochuli, P., Colin, J. \& Vigran, J.O. 1989: Triassic biostratigraphy of the Barents Sea area. In Collinson, J.D. (ed.): Correlation in Hydrocarbon Exploration, Graham \& Trotman, London, pp. 131-153. https://doi.org/10.1007/978-94-009-1149-9_12.

Hwang, I.G. \& Heller, P.L. 2002: Anatomy of a transgressive lag: Panther Tongue Sandstone, Star Point Formation, central Utah. Sedimentology 49, 977-999.

https://doi.org/10.1046/j.1365-3091.2002.00486.x.

Høy, T. \& Lundschien, B.A. 2011: Triassic deltaic sequences in the northern Barents Sea. In Spencer, A.M., Embry, A.F., Gautier, D.L., Stoupakova, A.V. \& Sørensen, K. (eds.): Arctic Petroleum Geology, Geological Society of London Memoirs 35, pp. 249-260. https://doi.org/10.1144/M35.15.

Håkansson, E. \& Stemmerik, L. 1989: Wandel Sea Basin-A new synthesis of the Late Paleozoic to Tertiary accumulation in North Greenland. Geology 17, 683-686. https://doi.org/10.1130/0091-7613(1989)017<0683:WSBANS>2.3.CO;2.

Johannessen, E.P. \& Embry, A.F. 1989: Sequence correlation: Upper Triassic to Lower Jurassic succession, Canadian and Norwegian Arctic. In Collinson, J.D. (ed.): Correlation in Hydrocarbon Exploration, Graham \& Trotman, London, pp. 155-170. https://doi.org/10.1007/978-94-009-1149-9_13.

Johnson, H. \& Baldwin, C. 1996: Chapter 7 - Shallow Clastic Seas. In Reading, H.G. (ed.): Sedimentary Environments: Processes, Facies and Stratigraphy, Third edition, Blackwell Science, Oxford, pp. 232280.

Kidwell, S.M. 1989: Stratigraphic condensation of marine transgressive records: origin of major shell deposits in the Miocene of Maryland. The Journal of Geology 97, 1-24. https://doi.org/10.1086/629278.

Kidwell, S.M. 1993: Taphonomic expressions of sedimentary hiatuses: field observations on bioclastic concentrations and sequence anatomy in low, moderate and high subsidence settings. Geologische Rundschau 82, 189-202. https://doi.org/10.1007/BF00191825.

Klausen, T.G., Ryseth, A.E., Helland-Hansen, W., Gawthorpe, R. \& Laursen, I. 2015: Regional development and sequence stratigraphy of the Middle to Late Triassic Snadd Formation, Norwegian Barents Sea. Marine and Petroleum Geology 62, 102-122. https://doi.org/10.1016/j.marpetgeo.2015.02.004.

Klausen, T.G., Müller, R., Slama, J. \& Helland-Hansen, W. 2017: Evidence for Late Triassic provenance areas and Early Jurassic sediment supply turnover in the Barents Sea Basin of northern Pangea. Lithosphere 9, 14-28. https://doi.org/10.1130/L556.1.

Klausen, T.G., Müller, R., Sláma, J., Olaussen, S., Rismyhr, B. \& HellandHansen, W. 2018: Depositional history of a condensed shallow marine reservoir succession: stratigraphy and detrital zircon geochronology of the Jurassic Stø Formation, Barents Sea. Journal of the Geological Society 175, 130-145. https://doi.org/10.1144/jgs2017-024.

Koevoets, M.J., Abay, T., Hammer, Ø. \& Olaussen, S. 2016: Highresolution organic carbon-isotope stratigraphy of the Middle Jurassic-Lower Cretaceous Agardhfjellet Formation of central Spitsbergen, Svalbard. Palaeogeography, Palaeoclimatology, Palaeoecology 449, 266-274. https://doi.org/10.1016/j.palaeo.2016.02.029.

Koevoets, M.J., Hammer, Ø., Olaussen, S., Senger, K. \& Smelror, M. 2019: Integrating subsurface and outcrop data of the Middle Jurassic to Lower Cretaceous Agardhfjellet Formation in central Spitsbergen. Norwegian Journal of Geology 99, 213-246. https://dx.doi.org/10.17850/njg98-4-01.

Kopik, J. \& Wierzbowski, A. 1988: Ammonites and stratigraphy of the Bathonian and Callovian at Janusfjellet and Wimanfjellet, Sassenfjorden, Spitsbergen. Acta Palaeontologica Polonica 33, 145-168.

Koppelhus, E.B. \& Dam, G. 2003: Palynostratigraphy and palaeoenvironments of the Rævekløft, Gule Horn and Ostreaelv Formations (Lower-Middle Jurassic), Neill Klinter Group, Jameson Land, East Greenland. Geological Survey of Denmark and Greenland Bulletin 1,723-775. 
Korčinskaya, M.V. 1980: Rannenorijskaja fauna arhipelaga Sval'bard (Early Norian fauna of the archipelago of Svalbard). In Semevskij, D.V. (ed.): Geologija osadočnogo čehla arhipelaga Sval'bard. (Geology of the sedimentary platform cover of the archipelago of Svalbard), NIIGA, Leningrad, pp. 30-43 (in Russian).

Krajewski, K.P. 1990: Phosphoritization in a starved shallow shelf environment: the Brentskardhaugen Bed (Toarcian-Bajocian) in Spitsbergen. Polish Polar Research 11,331-334.

Krajewski, K.P. 1992: Phosphorite-bearing sequence of the Wilhelmøya Formation at Hornsund and along western coast of Sørkapp Land, Spitsbergen. Studia Geologica Polonica 98, 201-233.

Lord, G.S., Solvi, K.H., Ask, M., Mørk, A., Hounslow, M.W. \& Paterson, N.W. 2014: The Hopen Member: A new member of the Triassic De Geerdalen Formation, Svalbard. Norwegian Petroleum Directorate Bulletin 11, 81-96.

Lord, G.S., Johansen, S.K., Støen, S.J. \& Mørk, A. 2017: Facies development of the Upper Triassic succession on Barentsøya, Wilhelmøya and NE Spitsbergen, Svalbard. Norwegian Journal of Geology 97, 33-62. https://doi.org/10.17850/njg97-1-03.

Loutit, T.S., Hardenbol, J., Vail, P.R. \& Baum, G.R. 1988: Condensed sections: the key to age determination and correlation of continental margin sequences. In Wilgus, C., Hastings, B., Kendall, C., Posamentier, H., Ross, C. \& Van Wagoner, J. (eds.): Sea Level Changes-An Integrated Approach, Society for Sedimentary Geology Special Publication 42, pp. 183-213. https://doi.org/10.2110/pec.88.01.0183.

Lund, J.J. 1977: Rhaetic to Lower Jurassic palynology of the onshore south-eastern North Sea Basin. Danmarks Geologiske Undersøgelse II 109, pp. 1-129.

Løfaldi, M. \& Nagy, J. 1980: Foraminiferal stratigraphy of Jurassic deposits on Kongsøya, Svalbard. Norsk Polarinstitutt Skrifter 172, 63-97.

Maceachern, J.A., Pemberton, S.G., Bann, K.L. \& Gingras, M.K. 2007: Departures from the archetypal ichnofacies: effective recognition of environmental stress in the rock record. In MacEachern, J.A., Bann, K.L., Gingras, M.K. \& Pemberton, S.G. (eds.): Applied Ichnology, Society for Sedimentary Geology Short Course Notes 52, pp. 65-93.

Macquaker, J., Taylor, K., Young, T. \& Curtis, C. 1996: Sedimentological and geochemical controls on ooidal ironstone and 'bonebed'formation and some comments on their sequencestratigraphical significance. In Hesselbo, S.P. \& Parkinson, D.N. (eds.): Sequence Stratigraphy in British Geology, Geological Society of London Special Publication 103, pp. 97-107. https://doi.org/10.1144/GSL.SP.1996.103.01.07.

Maher Jr., H.D. 1989: A storm-related orogin for the Jurassic Brentskardhaugen Bed of Spitsbergen, Norway. Polar Research 7, 67-77.https://doi.org/10.1111/j.1751-8369.1989.tb00605.x.

Mueller, S., Veld, H., Nagy, J. \& Kürschner, W.M. 2014: Depositional history of the Upper Triassic Kapp Toscana Group on Svalbard, Norway, inferred from palynofacies analysis and organic geochemistry. Sedimentary Geology 310, 16-29. https://doi.org/10.1016/j.sedgeo.2014.06.003.

Mulder, T., Syvitski, J.P.M., Migeon, S., Faugeres, J.C. \& Savoye, B. 2003: Marine hyperpycnal flows: initiation, behavior and related deposits: A review. Marine and Petroleum Geology 20, 861-882. https://doi.org/10.1016/j.marpetgeo.2003.01.003.

Mulrooney, M.J., Larsen, L., Rismyhr, B., Van Stappen, J., Senger, K., Braathen, A., Mørk, M.B., Olaussen, S., Cnudde, V. \& Ogata K. 2019: Fluid flow properties of a potential unconventional $\mathrm{CO}_{2}$ storage unit in central Spitsbergen: the Upper Triassic to Middle Jurassic Wilhelmøya Subgroup. Norwegian Journal of Geology 99, 279-310. https://doi.org/10.17850/njg002.

Mørk, A. \& Smelror, M. 2001: Correlation and non-correlation of high order Circum-Arctic Mesozoic sequences. Polarforschung 69, 65-72.
Mørk, A., Knarud, R. \& Worsley, D. 1982: Depositional and diagenetic environments of the Triassic and Lower Jurassic succession of Svalbard. In Embry, A.F. \& Balkwill, H.R. (eds.): Arctic Geology and Geophysics: Proceedings of the Third International Symposium on Arctic Geology, Canadian Society of Petroleum Geologists Memoir 8, pp. 371-398.

Mørk, A., Embry, A.F. \& Weitschat, W. 1989: Triassic transgressiveregressive cycles in the Sverdrup Basin, Svalbard and the Barents Shelf. In Collinson, J.D. (ed.): Correlation in Hydrocarbon Exploration, Graham \& Trotman, London, pp. 113-130. https://doi.org/10.1007/978-94-009-1149-9_11.

Mørk, A., Dallmann, W.K., Dypvik, H., Johannessen, E.P., Larssen, G.B., Nagy, J., Nøttvedt, A., Olaussen, S., Pčelina, T.M. \& Worsley, D. 1999: Mesozoic Lithostratigraphy. In Dallmann, W.K. (ed.): Lithostratigraphic Lexicon of Svalbard: Review and Recommendations for Nomenclature use, Norsk Polarinstitutt, pp. 127-214.

Mørk, M.B.E. 1999: Compositional variations and provenance of Triassic sandstones from the Barents Shelf. Journal of Sedimentary Research 69, 690-710.

https://doi.org/10.1306/D4268A6D-2B26-11D7-8648000102C1865D.

Mørk, M.B.E. 2013: Diagenesis and quartz cement distribution of lowpermeability Upper Triassic-Middle Jurassic reservoir sandstones, Longyearbyen $\mathrm{CO}_{2}$ lab well site in Svalbard, Norway. American Association of Petroleum Geologists Bulletin 97, 577-596. https://doi.org/10.1306/10031211193.

Nagy, J. \& Basov, V.A. 1998: Revised foraminiferal taxa and biostratigraphy of Bathonian to Ryazanian deposits in Spitsbergen. Micropaleontology 44, 217-255. https://doi.org/10.2307/1486047.

Nagy, J. \& Berge, S.H. 2008: Micropalaeontological evidence of brackish water conditions during deposition of the Knorringfjellet Formation, Late Triassic-Early Jurassic, Spitsbergen. Polar Research 27, 413-427. https://doi.org/10.3402/polar.v27i3.6184.

Nagy, J., Hess, S., Dypvik, H. \& Bjærke, T. 2011: Marine shelf to paralic biofacies of Upper Triassic to Lower Jurassic deposits in Spitsbergen. Palaeogeography, Palaeoclimatology, Palaeoecology 300, 138-151. https://doi.org/10.1016/j.palaeo.2010.12.018.

Nummedal, D. \& Swift, D.J.P. 1987: Transgressive stratigraphy at sequence-bounding unconformities: some principles derived from Holocene and Cretaceous examples. In Nummedal, D., Pilkey O.H. \& Howard, J.D. (eds.): Sea-level fluctuations and coastal evolution, Society for Sedimentary Geology Special Publication 41, pp. 241-260. https://doi.org/10.2110/pec.87.41.0241.

Nøttvedt, A., Cecchi, M., Gjelberg, J.G., Kristensen, S.E., Lønøy, A., Rasmussen, A., Rasmussen, E., Skott, P.H. \& Van Veen, P.M. 1993a: Svalbard-Barents Sea correlation: a short review. In Vorren, T.O., Bergsager, E., Dahl-Stamnes, Ø.A., Holter, E., Johansen, B., Lie, E. \& Lund, T.B. (eds.): Arctic Geology and Petroleum Potential, Norwegian Petroleum Society Special Publication 2, pp. 363-375. https://doi.org/10.1016/B978-0-444-88943-0.50027-7.

Nøttvedt, A., Livbjerg, F., Midbøe, P.S. \& Rasmussen, E. 1993b: Hydrocarbon potential of the central Spitsbergen basin. In Vorren, T.O., Bergsager, E., Dahl-Stamnes, Ø.A., Holter, E., Johansen, B. \& Lund, T.B. (eds.): Arctic Geology and Petroleum Potential, Norwegian Petroleum Society Special Publication 2, pp. 333-361. https://doi.org/10.1016/B978-0-444-88943-0.50026-5.

Odin, G.S. \& Matter, A. 1981: De glauconiarum origine. Sedimentology 28, 611-641. https://doi.org/10.1111/j.1365-3091.1981.tb01925.x.

Ogata, K., Senger, K., Braathen, A., Tveranger, J. \& Olaussen, S. 2012: The importance of natural fractures in a tight reservoir for potential CO2 storage: a case study of the Upper Triassic-Middle Jurassic Kapp Toscana Group (Spitsbergen, Arctic Norway). In Spence, G.H., Redfern, J., Aguilera, R., Bevan, T.G., Cosgrove, J.W., Couples, G.D. \& Daniel, J.M. (eds.): Advances in the Study of Fractured Reservoirs, Geological Society of London Special Publication 374, pp. 395-415. https://doi.org/10.1144/SP374.9. 
Ogata, K., Senger, K., Braathen, A., Tveranger, J. \& Olaussen, S. 2014: Fracture systems and meso-scale structural patterns in the siliciclastic Mesozoic reservoir-caprock succession of the Longyearbyen $\mathrm{CO}_{2}$ Lab project: implications for geologic $\mathrm{CO}_{2}$ sequestration on Central Spitsbergen, Svalbard. Norwegian Journal of Geology 94, 121-154.

Olaussen, S., Dalland, A., Gloppen, T.G. \& Johannessen, E. 1984: Depositional environment and diagenesis of Jurassic reservoir sandstones in the eastern part of Troms I area. In Spencer, A.M., Johnsen, S.O., Mørk, A., Nysæther, E., Songstad, P. \& Spinnangr, A. (eds.): Petroleum Geology of the North European Margin, Norwegian Petroleum Society, Graham \& Trotman, pp. 61-79. https://doi.org/10.1007/978-94-009-5626-1_6.

Orbell, G. 1973: Palynology of the British Rhaeto-Liassic. Bulletin of the Geological Survey of Great Britain 44, 1-44.

Paterson, N.W. \& Mangerud, G. 2015: Late Triassic (CarnianRhaetian) palynology of Hopen, Svalbard. Review of Palaeobotany and Palynology 220, 98-119. https://doi.org/10.1016/j.revpalbo.2015.05.001.

Pčelina, T. 1980: Novye dannye po pograničnym slojam triasa i jury $\mathrm{v}$ arhipelage Sval'bard (New data on the boundary strata of the Triassic and Jurassic in the Svalbard archipelago). In Semevskij, D.V. (ed.): Geologija osadočnogo čehla arhipelaga Sval'bard (Geology of the Sedimentary Cover of the Svalbard Archipelago), NIIGA, Leningrad, pp. 44-60 (in Russian).

Pedersen, T., Harms, J., Harris, N., Mitchell, R. \& Tooby, K. 1989: The role of correlation in generating the Heidrun Field geological model. In Collinson, J.D. (ed.): Correlation in Hydrocarbon Exploration, Graham \& Trotman, London, pp. 327-338. https://doi.org/10.1007/978-94-009-1149-9_25.

Petrov, O.V., Sobolev, N.N., Koren, T.N., Vasiliev, V.E., Petrov, E.O., Larssen, G.B. \& Smelror, M. 2008: Palaeozoic and Early Mesozoic evolution of the East Barens and Kara Seas sedimentary basins. Norwegian Journal of Geology 88, 227-234.

Posamentier, H.W. \& Allen, G.P. 1999: Siliciclastic Sequence Stratigraphy-Concepts and Applications. Society for Sedimentary Geology Concepts in Sedimentology and Paleontology 7, Society for Sedimentary Geology, Tulsa, $212 \mathrm{pp}$. https://doi.org/10.2110/csp.99.07.

Poulsen, N.E. \& Riding, J.B. 2003: The Jurassic dinoflagellate cyst zonation of Subboreal Northwest Europe. Geological Survey of Denmark and Greenland Bulletin 1, 115-144.

Reading, H.G. \& Collinson, J.D. 1996: Chapter 6 - Clastic coasts. In Reading, H.G. (ed.): Sedimentary Environments: Processes, Facies and Stratigraphy, Third edition, Blackwell Science, Oxford, pp. 154-231.

Riding, J.B. 1984: A plynological investigation of Toarcian to early Aalenian strata from the Blea Wyke area, Ravenscar, North Yorkshire. Proceedings of the Yorkshire Geological Society 45, 109122. https://doi.org/10.1144/pygs.45.1-2.109.

Riding, J.B. \& Thomas, J.E. 1992: Dinoflagellate cysts of the Jurassic System. In Powell, A.J. (ed.): A stratigraphic index of dinoflagellate cysts, Chapman \& Hall, pp. 7-97. https://doi.org/10.1007/978-94-011-2386-0_2.

Riis, F., Lundschien, B.A., Høy, T., Mørk, A. \& Mørk, M.B.E. 2008: Evolution of the Triassic shelf in the northern Barents Sea region. Polar Research 27, 318-338.

https://doi.org/10.1111/j.1751-8369.2008.00086.x.

Ritzmann, O. \& Faleide, J.I. 2009: The crust and mantle lithosphere in the Barents Sea/Kara Sea region. Tectonophysics 470, 89-104. https://doi.org/10.1016/j.tecto.2008.06.018.

Ryseth, A. 2014: Sedimentation at the Jurassic-Triassic boundary, south-west Barents Sea: indication of climate change. In Martinius, A.W., Ravnås, R., Howell, J.A, Steel, R.J. \& Wonham, J.P. (eds.): From Depositional Systems to Sedimentary Successions on the Norwegian Continental Margin, Special Publication 46 of the International Association of Sedimentologists, pp. 187-214.

https://doi.org/10.1002/9781118920435.ch9.
Rød, R.S., Hynne, I.B. \& Mørk, A. 2014: Depositional environment of the Upper Triassic De Geerdalen Formation - An E-W transect from Edgeøya to Central Spitsbergen, Svalbard. Norwegian Petroleum Directorate Bulletin 11,21-40.

Sawyer, M.J. \& Keegan, J.B. 1996: Use of palynofacies characterization in sand-dominated sequences, Brent Group, Ninian Field, UK North Sea. Petroleum Geoscience 2, 289-297. https://doi.org/10.1144/petgeo.2.4.289.

Senger, K., Tveranger, J., Ogata, K., Braathen, A., \& Planke, S. 2014: Late Mesozoic magmatism in Svalbard: A review. Earth-Science Reviews $139,123-144$. https://doi.org/10.1016/j.earscirev.2014.09.002.

Senger, K., Tveranger, J., Braathen, A., Olaussen, S., Ogata, K. \& Larsen, L. 2015: CO2 storage resource estimates in unconventional reservoirs: insights from a pilot-sized storage site in Svalbard, Arctic Norway. Environmental Earth Sciences 73, 3987-4009. https://doi.org/10.1007/s12665-014-3684-9.

Smelror, M. 1988: Bathonian to early Oxfordian dinoflagellate cysts and acritarchs from Kong Karls Land, Svalbard. Review of Palaeobotany and Palynology 56, 275-304. https://doi.org/10.1016/0034-6667(88)90061-9.

Smelror, M. \& Below, R. 1992: Dinoflagellate biostratigraphy of the Toarcian to Lower Oxfordian (Jurassic) of the Barents Sea region. In Vorren, T.O., Bergsager, E., Dahl-Stamnes, Ø.A., Holter, E., Johansen, B., Lie, E. \& Lund, T.B. (eds.): Arctic Geology and Petroleum Potential, Norwegian Petroleum Society Special Publication 2, pp. 495-513. https://doi.org/10.1016/B978-0-444-88943-0.50035-6.

Smelror, M., Petrov, O., Larssen, G.B. \& Werner, S.C. 2009: Geological History of the Barents Sea. Norges geologiske undersøkelse, Trondheim, $134 \mathrm{pp}$.

Smith, D.G. 1974: Late Triassic pollen and spores from the Kapp Toscana Formation, Hopen, Svalbard - a preliminary account. Review of Palaeobotany and Palynology 17, 175-178. https://doi.org/10.1016/0034-6667(74)90098-0.

Smith, D.G. 1975: The stratigraphy of Wilhelmøya and Hellwaldfjellet, Svalbard. Geological Magazine 112, 481-491. https://doi.org/10.1017/S0016756800046203.

Smith, D.G. 1982: Stratigraphic significance of a palynoflora from ammonoid-bearing Early Norian strata in Svalbard. Newsletters on Stratigraphy 11, 154-161. https://doi.org/10.1127/nos/11/1982/154.

Smith, D.G., Harland, W.B. \& Hughes, N.F. 1975: Geology of Hopen, Svalbard. Geological Magazine 112, 1-23. https://doi.org/10.1017/S0016756800045544.

Steel, R.J. \& Worsley, D. 1984: Svalbard's Post-Caledonian strata-an atlas of sedimentational patterns and palaeogeographic evolution. In Spencer, A.M., Johnsen, S.O., Mørk, A., Nysæther, E., Songstad, P. \& Spinnangr, A. (eds.): Petroleum Geology of the North European Margin, Norwegian Petroleum Society, Graham \& Trotman, pp. 109-135. https://doi.org/10.1007/978-94-009-5626-1_9.

Steel, R., Gjelberg, J., Helland-Hansen, W., Kleinspehn, K., Nøttvedt, A. \& Rye-Larsen, M. 1985: The Tertiary strike-slip basins and orogenic belt of Spitsbergen. In Biddle, K.T. \& Christie-Blick, N. (eds.): StrikeSlip Deformation, Basin Formation, and Sedimentation, Society for Sedimentary Geology Special Publication 37, pp. 339-360. https://doi.org/10.2110/pec.85.37.0319.

Suneby, L. \& Hills, L. 1988: Palynological zonation of the Heiberg Formation (Triassic-Jurassic) eastern Sverdrup Basin, Arctic Canada. Bulletin of Canadian Petroleum Geology 36, 347-361.

Suter, J.R. 2006: Clastic Shelves. In Posamentier, H.W. \& Walker, R.G. (eds.): Facies Models Revisited, Society for Sedimentary Geology Special Publication 84, pp. 339-397. https://doi.org/10.2110/pec.06.84.0339.

Van Stappen, J., De Kock, T., Boone, M., Olaussen, S. \& Cnudde, V. 2014: Pore-scale characterization and modelling of $\mathrm{CO}_{2}$ flow in tight sandstones using X-ray micro-CT; Knorringfjellet Formation of the Longyearbyen $\mathrm{CO}_{2}$ Lab, Svalbard. Norwegian Journal of Geology 94, 201-215. 
Van Wagoner, J., Mitchum, R., Campion, K. \& Rahmanian, V. 1990: Siliciclastic Sequence Stratigraphy in Well Logs, Cores, and Outcrops: Concepts for High-Resolution Correlation of Time and Facies. American Association of Petroleum Geologists Methods in Exploration Series 7, pp. 1-55.

https://doi.org/10.1306/BF9AB431-0EB6-11D7-8643000102C1865D.

Vigran, J.O., Mangerud, G., Mørk, A., Worsley, D. \& Hochuli, P.A. 2014: Palynology and geology of the Triassic succession of Svalbard and the Barents Sea. Geological Survey of Norway Special Publication 14, $1-269$.

Von Hillebrandt, A., Krystyn, L. \& Kuerschner, W. 2007: A candidate GSSP for the base of the Jurassic in the Northern Calcareous Alps (Kuhjoch section, Karwendel Mountains, Tyrol, Austria). International Subcommission on Jurassic Stratigraphy Newsletter 34, $2-20$.

Wierzbowski, A., Kulicki, C. \& Pugaczewska, H. 1981: Fauna and stratigraphy of the uppermost Triassic and the Toarcian and Aalenian deposits in the Sassenfjorden, Spitsbergen. Acta Palaeontologica Polonica 26, 195-237.

Worsley, D. 1973: The Wilhelmoya Formation - a new lithostratigraphical unit from the Mesozoic of eastern Svalbard. Norsk Polarinstitutt Årbok 1971,7-16.

Worsley, D. 2008: The post-Caledonian development of Svalbard and the western Barents Sea. Polar Research 27, 298-317.

https://doi.org/10.1111/j.1751-8369.2008.00085.x. 